\title{
Forum Non Conveniens: A Doctrine in Search of a Role
}

\author{
Margaret G. Stewart†
}

If the law is a seanless web, certainly one of its stickiest strands is the concept of contacts-contacts between a defendant, a forum, and a litigation. Courts rely on such contacts to determine whether a forum may properly assert jurisdiction over a defendant, ${ }^{1}$ whether the law of the forum may properly be used to regulate the conduct in controversy, ${ }^{2}$ and whether the suit ought be dismissed in order that it may be more conveniently tried elsewhere. ${ }^{3}$

$\dagger$ Associate Professor of Law, IIT Chicago-Kent College of Law. B.A. Kalamazoo College, 1968; J.D. Northwestern University School of Law, 1971. I wish to thank my colleagues, Stuart Deutsch, Warren Heindl, Linda Hirschman, and particularly Joan Steinman and David Gerber for their generous help and willing comments on various drafts of this Article.

1. Shaffer v. Heitner, 433 U.S. 186, 204 (1977); see infra note 10.

2. See, e.g., Hellenic Lines Ltd. v. Rhoditis, 398 U.S. 306, 309-10 (1970); Lauritzen v. Larsen, 345 U.S. 571, 582 (1953); Steele v. Bulova Watch Co., 344 U.S. 280, 286-87 (1952); Straub v. Vaisman \& Co., 540 F.2d 591, 595 (3d Cir. 1970); Psimenos v. E.F. Hutton \& Co., 722 F.2d 1041, 1047-48 (2d Cir. 1983).

3. Such dismissals are based upon the doctrine of forum non conveniens. In Gulf Oil Corp. v. Gilbert, 330 U.S. 501 (1947) the Supreme Court extended from admiralty to general jurisprudence the concept that "a court may resist imposition upon its jurisdiction even when jurisdiction is authorized by the letter of a general venue statute." Id. at 507. Gilbert posited the following criteria to determine whether the institution of an authorized suit constitutes such an imposition, justifying dismissal:

An interest to be considered, and the one likely to be most pressed, is the private interest of the litigant. Important considerations are the relative ease of access to sources of proof; availability of compulsory process for attendance of unwilling, and the cost of obtaining attendance of willing, witnesses; possibility of view of premises, if view would be appropriate to the action; and all otlier practical problems that make trial of a ease easy, expeditious and inexpensive. There may also be questions as to the enforcibility [sic] of a judgment if one is obtained. The court will weigh relative advantages and obstacles to fair trial. It is often said that the plaintiff may not, by choice of an inconvenient forum, "vex," "harass," or "oppress" the defendant by inflicting upon him expense or trouble not necessary to his own right to pursue his remedy. But unless the balance is strongly in favor of the defendant, the plaintiff's choice of forum should rarely be disturbed.

Factors of public interest also have place in applying the doctrine. Administrative difficulties follow for courts when litigation is piled up in congested centers instead of being handled at its origin. Jury duty is a burden that ought not to be imposed upon the people of a community which has no relation to the litigation. In cases which touch the affairs of many persons, there is reason for holding the trial in their view and reach rather than in remote parts of the country where they can learn of it by report only. There is a local interest in having localized controversies decided at loome. There is an appropriateness, too, in having the trial of a diversity case in a forum that is at home with the state law that must govern the case, rather tlian having a court in some other forum untangle problems in conflict of laws, and in law foreign to itself.

$I d$. at 508-09 (footnotes omitted). Not only federal courts but most state courts that aceept the doctrine follow this statement of it. This congruity has obviated, for the most part, the need to 
In each of these three inquiries, two concerns are intertwined. The first is that the practical burden of litigating in the forum not be unduly heavy for the parties, particularly for the defendant. ${ }^{4}$ Thus, in the personal jurisdiction inquiry, the court asks whether the defendant, in a purposeful or intentional fashion, has availed himself of the privilege of conducting activities in the forum. ${ }^{5}$ Because such activities benefit the defendant it is not unfair to impose upon the defendant a parallel burden to defend himself in the forum im a lawsuit arising out of those activities. ${ }^{6}$ In determining whether the forum has prescriptive jurisdiction over the conduct in controversy, ${ }^{7}$ the court again examines the defendant's contacts with the forum to see whether use of forum law to judge his conduct is reasonable in hight of the defendant's legitimate expectations. ${ }^{8}$ Finally, in the forum non conveniens inquiry, the court focuses on such matters as the location of evidence and of witnesses in order to assess the degree of actual difficulty hitigating in the chosen forum will impose. ${ }^{9}$ While these contacts between the litigation and the forum are not necessarily the equivalent of contacts between the defendant and the forum,

determine whether a federal court must follow state law in deciding whether to dismiss a suit when subject matter jurisdiction is based on diversity. In the absence of conflict between state and federal doctrines of forum non conveniens, Erie R.R., v. Tompkins, 304 U.S. 64 (1938), does not come into play.

Today, the doctrine is used in the federal system only if the alternative forum is not another federal district court (see infra note 18) and, therefore, is most frequently raised in conjunction with a discussion of prescriptive jurisdiction. No mechanism, however, permits the transfer of cases between states. The doctrine therefore retains its importance in both systems, although for different reasons.

4. The role of the plaintiff's citizenship is considered infra at note 83 and accompanying text.

5. See, e.g., Hanson v. Denckla, 357 U.S. 235, 253 (1958).

6. Cf. Burger King Corp. v. Rudzewicz, 105 S. Ct. 2174, 2183 (1985). The extent of that burden, and therefore the fairness of its imposition, is ordinarily a function of the practical convenience of litigating in the forum. Only when the defendant is a citizen of the fornm is the burden properly imposed without reference to such convenience. See infra notes 87-98 and accompanying text. The degree to which the burden parallels the benefit obtained by the defendant is one central issue in determining the constitutional validity of an assertion of jurisdiction. The distinction between causes of action that are related to acts of the defendant in thc forum and those that are not is a recurring theine in this Article. The distinction is particularly important in the context of personal rather than prescriptive jurisdiction.

7. The term "prescriptive jurisdiction" derives from international law. It is used in this Article to refer to the ability of a state or nation to regulate conduct. A foruin's prescriptivc jurisdiction determination should not be confused with its choice of law inquiry. The prescriptive jurisdiction determination is a threshold one: Is there a nexus between the regulating authority and the conduct in question such that applying the regulation to the conduct in question would be fair? Once the forum determines that sueh a nexus exists, the prescriptive jurisdiction inquiry is ended. If more than one state or nation may assert prescriptive jurisdiction, the determination of which law to apply is made according to the foruin's choice of law rules. Of course, to the extent that the prescriptive jurisdictional inquiry takes into account the competing interests of other sovereigns in regulating the same activity, an assertion of prescriptive jurisdiction may obviate the need for any choice of law determination. See infra Part II.

8. See cases cited infra in Part II.

9. See supra note 3 . 
they are related to such contacts and are also considered in both personal and prescriptive jurisdiction decisions.

The second concern underlying the courts' focus on contacts is with sovereign authority and its limitations. In the context of personal jurisdiction, that concern itself is at least theoretically two-fold. The United States Supreme Court has held that the assertion of such jurisdiction demands a justification based botli upon the defendant's relation with the forum and upon the effect that the assertion will have on the sovereignty of other fora. ${ }^{10}$ However, since inore than one forum often may assert personal jurisdiction over a single defendant based upon different contacts between each forum and that defendant, as a practical matter the interests of the cliosen forum determine the propriety of its jurisdiction.

In the context of prescriptive jurisdiction-the ability of a state to regulate the conduct of parties-tlie theoretical duality of the courts' focus is less clear. Constitutionally, it is apparent tliat a state witli only minimal interest in tlie parties' conduct is free to regulate tliat conduct and to clioose to apply its regulation to a dispute before its courts, ${ }^{11}$ even if the interests of competing states are stronger. Tlie Constitution does not require any balancing of tliose competing interests but only requires that the state regulating an activity liave some contact with it. ${ }^{12}$ When

10. In Pennoyer v. Neff, 95 U.S. 714 (1877), for example, the Court interpreted the restraint imposed upon a state's assertion of jurisdiction by the fourteenth amendment as coextensive with that imposed by "public" (international) law: within a state's boundaries, its authority was exclusive; outside its boundaries, it lacked any authority. See id. at 730 . While the current understanding of due process focuses less on territorial restrictions than on minimum contacts between the defendant and the forum asserting jurisdiction, the Supreme Court continues to insist that the restraint not only protects defendants but is an essential attribute of state sovereignty. World-Wide Volkswagen Corp. v. Woodson, 444 U.S. 286, 292 (1980); Hanson v. Denckla, 357 U.S. 235, 251 (1958). However, recent personal jurisdiction decisions of the Supreme Court increasingly focus on the "individual liberty interest preserved by the Due Process Clause" rather than concerns of federalism. Burger King Corp. v. Rudzewicz, 105 S. Ct. 2174, 2182 n.13 (1985) (quoting Insurance Corp. of Ireland, Ltd. v. Compagnie des Bauxites de Guinee, 456 U.S. 694, 702 n.10 (1982)). That a defendant can consent to personal jurisdiction supports the conclusion that the primary interests protected by this restraint are private. Nonetheless, continuing to frame the issue in terms of state boundaries undercuts the notion that sovereign interests are completely irrelevant. If a defendant lives within a mile of the courthouse where litigation is brought, but in a neighboring state, and if he lacks the requisite purposeful contacts with the forum, jurisdiction is improper. But see World-Wide Volkswagen Corp. v. Woodson, 444 U.S. 286, $307-13$ (1980) (Brennan, J., dissenting) (arguing, without reference to state boundaries, that a defendant's right to due process cannot be offended if he suffers no inconvenience).

11. Of course, a state may be free to regulate conduct but choose not to do so, applying instead the law of another state to controversies involving the conduct brought before its courts. If a state may properly exercise prescriptive jurisdiction over the conduct of parties, there is no constitutional restraint on the process by which it decides the choice of law issue. In other words, decisions allegedly restraining state choice of law in fact restrain assertions of prescriptive jurisdiction and govern only "false problem" cases. See Currie, The Constitution and the Choice of Law: Governmental Interests and the Judicial Function, in SELECTED ESSAYS ON THE CONFLICT OF LAwS 188, 193 (1963); see also supra note 7 and infra notes 12 \& 194-204 and aceompanying text.

12. The constitutional source of restraint upon a state's choice of law is twofold. If the source 
the issue of prescriptive jurisdiction is presented as a potential conflict between two nations, however, some courts have recently come to consider the interests of the coinpeting sovereign in determining the propriety of regulating conduct according to United States statutes. Those coinpeting interests inay preclude United States regulation, even if United States regulation would otherwise be justifiable. ${ }^{13}$

Similarly, in the context of forum non conveniens, the theoretical focus includes the interests of both the selected forum and the alternative forum. For example, when a court considers the state of the forum's docket and the burden imposed upon the community by requiring its citizens to assume jury duty, it is considering the interests of the selected forum. When a court recognizes that those affected by the controversy ought to have ready access to the proceeding and that local controversies ought to be decided at hoine, it is recognizing the interests of the alternative foruin. ${ }^{14}$ The potential for conflict between these interests is less than the potential for conflict in the context of the personal jurisdiction or prescriptive jurisdiction inquiries; indeed, in inost situations the interests of one foruin are reinforced by reference to the interests of the other. When, for example, jury duty is an inappropriate burden to impose upon an uninterested coinmunity, the alternative forum is ordinarily interested in having a local controversy decided locally. Thus, there is usually no need here to balance competing interests, a need most clearly seen in the context of prescriptive jurisdiction.

While consideration of contacts between the parties, the litigation, and the foruin is currently necessary to resolve at least three potential issues in any lawsuit, resolution of one does not compel a similar resolution of the other two. Thus, a state may properly assert personal jurisdic-

of competing law is a foreign nation, due process demands that there be some connection between the forum and the claim if the forum's law is to be used. Home Ins. Co. v. Dick, 28I U.S. 397, 410 (1930). More frequently, however, the choice is between the law of the forum and the law of another state. In that situation, an additional command, that "Full Faith and Credit shall be given in each State to the public Acts ... of every other State," is implicated. U.S. CoNST. art. IV, $\S 1$. The clause clcarly cannot be read to demand automatic deference by the forum to the statutes of another state with an interest in the controversy, but it could be read to demand that the forum identify and weigh the interests of that other state before automatically applying its own law. Alaska Packers Ass'n. v. Industrial Accident Comm'n, 294 U.S. 532, 547 (1935). However, it is not. The focus remains the interest of the forum; once an interest sufficient to permit use of forum law is identified, the constitutional inquiry is at an end. Pacific Employers Ins. Co. v. Industrial Accident Comm'n, 306 U.S. 493 (1939); see infra notes $149-53$ and accompanying text. For an argument that even the restraint currently imposed by the Court is constitutionally improper under either clause, see Whitten, The Constitutional Limitations on State Choice of Law: Full Faith and Credit, 12 MEM. ST. U.L. REv. 1 (1981), and Whitten, The Constitutional Limitations on State Choice of Law: Due Process, 9 Hastings Const. L.Q. 851 (1982).

13. See Timberlane Lumber Co. v. Bank of America, N.T. \& S.A., 749 F.2d 1378 (9th Cir. 1984), cert. denied, 105 S. Ct. 3514 (1985); Montreal Trading Ltd. v. Amax, Inc., 661 F.2d 864 (10th Cir. 1981), cert. denied, 455 U.S. 1001 (1982); see also infra note 88 and accompanying text.

14. See supra note 3. 
tion over a defendant and yet not have the authority to assert prescriptive jurisdiction over his conduct. ${ }^{15}$ Similarly, a state that would undeniably have power to apply its law to a suit brought before its courts may lack personal jurisdiction over the defendant. ${ }^{16}$ Finally, a state that may assert both personal and prescriptive jurisdiction may nonetheless dismiss a case brought in its courts under the doctrine of forum non conveniens. ${ }^{17}$

Unfortunately, the courts have never clearly explained why the same universe of contacts may compel dismissal on one ground and not on another. Perhaps because courts consider contacts so frequently, with respect to such different questions, they rarely explain why a particular group of contacts justifies a particular result. Too often, the ability to dismiss a lawsuit on one of the three grounds leads to summary resolution of the otlier issues, thus clouding the analysis to be used in the future witli respect to those issues.

This Article argues that the jurisdictional inquiries serve different purposes and require separate modes of analysis. When the jurisdictional inquiries are conducted properly, it becomes apparent that the doctrine of forum non convemiens has outlived its usefulness. ${ }^{18}$ The personal

15. If the justification for the assertion of personal jurisdiction involves contacts between the defendant and the forum that are related to the higation, such a result is unlikely. Nevertheless, such a result is possible if the recognized interests of another forum outweigh the interests of the chosen forum. If, however, personal jurisdiction is based upon contacts between the defendant and the forum that bear no relation to the litigation, such a result is highly probable.

16. See, e.g., World-Wide Volkswagen Corp. v. Woodson, 444 U.S. 286 (1980). The Court held only that personal jurisdiction was improper. Since the injury occurred in the forum state and the forum had an indisputable interest in regulating the safety of automobiles using its highways, it undeniably could have appled its law to the dispute. For a further discussion of World-Wide, see infra note 110 and accompanying text.

17. See Wells Fargo \& Co. v. Wells Fargo Express Co., 556 F.2d 406, 431 (9th Cir. 1977); $c f$. Southern Mach. Co. v. Mohasco Indus., 401 F.2d 374, 377 n.6 (6th Cir. 1968) (relying on the availability of the forum non conveniens doctrine to avoid any potential constitutional problems, due either to the fourteenth amendment or to the commerce clause, with an assertion of personal jurisdiction).

18. To the extent that the doctrine is used to choose between courts of the same sovereign, it retains validity. Both personal and prescriptive jurisdiction are concerned with the authority of a sovereign entity, not with how that entity itself decides to distribute judicial work. Thus, statutes like 28 U.S.C. $\$ 1404$ (a) ("For the convenience of parties and witnesses, in the interest of justice, a district court may transfer any civil action to any other district or division where it might have been brought."), which operate as an exception to general venue statutes, remain useful as a way of refining the choice of forum.

Recognition of the overlap between the concerns of forum non conveniens and modern notions of jurisdiction does not inevitably lead to a call for the abandonment of dual consideration of those factors. See Morley, Forum Non Conveniens: Restraining Long-Arm Jurisdiction, 68 Nw. U.L. REv. 24 (1973); Comment, Considerations of Choice of Law in the Doctrine of Forum Non Conveniens, 74 CALIF. L. REv. 565, 591-96 (1986). But such duality has been strenuously criticized in a recent, excellent article. See Stein, Forum Non Conveniens and the Redundancy of Court-Access Doctrine, 133 U. PA. L. REV. 781 (1985). The article initially sets out the overlap the author perceives between subject matter jurisdiction-in this Article identified as prescriptive jurisdiction, 
jurisdiction inquiry ought to take into account what courts in the context of forun 1 non conveniens refer to as the "private factors," those factors that relate to the burden imposed on the litigants by the plaintiff's choice of forun. Many cases disntissed under the doctrine of forum non conveniens should thus be disinissed for lack of personal jurisdiction over the defendant. The prescriptive jurisdiction inquiry ought to take into account the "public factors" of forum non conveniens, those factors that relate to the interests of the chosen forum and of other fora interested in the litigation. Cases in which personal jurisdiction is proper, but in which the law of another sovereign is to be applied, ought to be retained and decided in the original forum. Since the source of applicable law is itself a factor to be considered in assessing the burden of litigation, the use of foreign law need not result in disinissal of the lawsuit.

Part I of this Article analyzes the requirements of personal jurisdiction, focusing on the protection afforded to the defendant by the due process clause against distant and inconvenient litigation. The central focus of this jurisdictional inquiry is the relationship between the defendant's activities im the forum and the claim brouglit against him there. The traditional approach based upon the forum's power over the defendant has been severely eroded and should now be abolished as a basis of jurisdiction. If the claim against the defendant arises out of his activities in the forum, the forum inevitably will be a sufficiently convenient one to preclude dismissal of the suit under a properly utilized doctrine of forum non conveniens. If, on the other hand, the claim does not arise out of the defendant's activities in the forum, the forum is likely to be highly inconvenient, at least for tlie defendant and his witnesses. In some situations, personal jurisdiction is nonetheless justifiable because other factors outweigh the inconvenience. Absent those factors, however, jurisdiction should not be sustained unless it is no more mconvenient to litigate in the forum chosen by the plaintiff than it would be to litigate in the alternative forum. There is, then, no need for a doctrine other than personal jurisdiction to assure that a court consider the propriety of burdening a defendant in permitting litigation to proceed where it was filed.

Part II of this Article analyzes the requirements of prescriptive jurisdiction in a number of substantive areas and argues that it is necessary to consider the interests of alternative fora in regulating the defend-

see infra note 121-personal jurisdiction, venue, and forum non conveniens. Stein then traces the development of forum non conveniens in the United States, focusing on and persuasively criticizing first the two relevant Supreme Court cases and then the confusing and conflicting uses to which other courts have put the doctrine. In his conclusion, he calls for the emergence of a doctrine of "forum conveniens," under either the rubric of personal jurisdiction, if notions of territoriality can be overcome, or the rubric of subject matter jurisdiction, if they cannot. This Article thus begins where his leaves off and attempts to posit jurisdictional analyses that will obviate the need for a common law doctrine out of control. 
ant's conduct in order to assess the weight of the forum's interest in regulating that same conduct. This approach thus obviates the need for another doctrine to ensure consideration of competing sovereign interests. It also justifies the imposition on the court of the potential burden of hearing a case to be resolved under foreign law by reference to interests subsuined in either the personal or the prescriptive jurisdiction inquiry.

\section{I \\ Personal Jurisdiction And Forum Non Conveniens}

In order to comport with due process, assertion of personal jurisdiction over a defendant demands a certain relationship between the defendant, the litigation, and the forum. ${ }^{19}$ According to the Supreme Court, if there are minimum contacts between a defendant and the forum such that the maintenance of the suit does not offend traditional notions of fair play and substantial justice, jurisdiction may properly be asserted. ${ }^{20}$ The court must evaluate the contacts in relation to the fair and orderly administration of the laws, ${ }^{21}$ and there must be evidence of some intent on the part of the defendant to avail himself of the privilege of conducting activities in the forum, thus invoking the benefits and protections of its laws. ${ }^{22}$ In other words, the propriety of personal jurisdiction depends upon the facts of the case.

Assuming that the defendant has at some time engaged in activities in the forum, such activities may be either continuous and systematic (for example, the operation of a manufacturing plant im the forum) or single or occasional (driving a vehicle through the forum). Additionally, the cause of action brought against the defendant may be related to the activities in the foruin (negligent inanufacture of a product by the plant operated in the forum or a car accident in the forum) or unrelated to them (a claim of negligent design undertaken elsewhere of products manufactured in the forum plant or a claim for breach of contract outside the forum against the defendant who has driven through the foruin).

19. Shaffer v. Heitner, 433 U.S. 186, 204 (1977).

20. International Shoe Co. v. Washington, 326 U.S. 310,316 (1945).

21. Id. at 319 .

22. Hanson v. Denckla, 357 U.S. 235, 253 (1958). Burger King Corp. v. Rudzewicz, 105 S. Ct. 2174, 2181 (1985) seems to have changed the traditional word formula, though not the import of the constitutional test. Rather than use "minimum contacts" as a synonym for jurisdiction, the - Court stated, "[O]nce it has been decided that a defendant purposefully established minimum contacts within the forum State, these contacts may be considered in light of other factors to determine whether the assertion of personal jurisdiction would comport with "fair play and substantial justice." " $105 \mathrm{~S}$.Ct at 2184. If "minimum contacts" no longer assure proper jurisdiction, it is because that phrase is now the equivalent of "purposeful availment," a finding of which is necessary to, but not determinative of, jurisdiction. See infra Part I, Section $B(2)$. 


\section{A. Claims Arising Out of the Defendant's Activity in the Forum}

If a defendant has engaged in continuous and systematic business in the forum and is sued there because of alleged damage caused by those activities, the forum clearly has personal, as well as prescriptive, jurisdiction. Equally clearly, a motion to dismiss the claim on the grounds of forum non conveniens should fail. For example, International Shoe Co. v. Washington ${ }^{23}$ involved a claim by the state of Washington for unpaid, statutorily required contributions to its unemployment compensation fund. The state asserted its claim agaimst a corporation that had advertised for and solicited business in Washington and had employed citizens of Washington over a number of years. It was the defendant's business in the state that generated the clainied tax liability. Both personal and prescriptive jurisdiction were sustained, and no one could have successfully argued that some other forum was sufficiently more convenient to justify a forum non conveniens disniissal.

Even in situations where not all activity giving rise to the cause of action occurred in the forum, the result may well be the same. In Lehman v. Humphrey Cayman, Ltd., ${ }^{24}$ the Iowa widow of an Iowa decedent, killed in a boating accident in the Cayman Islands, sued the foreign franchisee of Holiday Inns in an Iowa district court for wrongful death. The district court demed the defendant's inotion to dismiss for lack of personal jurisdiction, but granted a dismissal based upon forum non conveniens. In reversing that dismissal, the circuit court frequently referred to the relationship between the two findings. The court einphasized that the defendants had "engaged in a systematic advertising effort to generate business in Iowa, the representations regarding the hotel and its facilities were directed at [decedent] in Iowa, and the hotel reservations were made through a travel agency in Iowa."25 Such solicitation of business in the forum constituted a purposeful act of the defendant, which was expected to benefit it, and to the extent the plaintiff's claim was based on breach of warranty rather than negligence in the Cayman Islands, it was related to the cause of action. It also generated a cognizable interest in Iowa, over and above its interest in providing a convenient forum for its injured citizens, since the state need not sit idly by while false and misleading information is provided to its citizens to lure them into out-ofstate activity.

While recognizing that the specific questions raised by the two motions to dismiss were distinct, the circuit court twice commented that to ignore, for purposes of forum non conveniens, the interests recognized

\footnotetext{
23. 326 U.S. 310 (1945).

24. 713 F.2d 339 (8th Cir. 1983).

25. Id. at 344 .
} 
in the context of jurisdiction was inconsistent and unfounded. ${ }^{26}$ Other facts of traditional concern under forum non convemiens analysis, for the most part, spoke to the relative burdens of defending in Iowa and proceeding in the Cayman Islands. The appellate court believed the weighing of burdens to be subsumed in the conceru for "fairness," reflected in the jurisdictional analysis. ${ }^{27}$

Of course, even if the plaintiff's claim arose only out of the defendant's contmuous activities in the forum, there might still exist a second, interested, and at least equally convenient foruin. Under the traditional forum non conveniens analysis, some such claims have been dismissed. Indeed, the most recent Supreme Court decision involving the doctrine, Piper Aircraft Co. v. Reyno, ${ }^{28}$ presented precisely this scenario. An aircraft, manufactured in Pennsylvania and incorporating propellers made in Ohio, was sold by Piper to an Ohio purchaser for use im the United States and ended up as part of a Scottish air-taxi service. The plane crashed in Scotland, killing the pilot and five passengers, all Scots. Suit was brought by the administratrix of the passengers' estates in California; the defendants removed the case to the federal court which transferred it to the Middle District of Pennsylvania. ${ }^{29}$ That court dismissed on grounds of forum non conveniens; ${ }^{30}$ the Third Circuit reversed; ${ }^{31}$ and the Suprene Court reversed the Third Circuit, reinstating the district court's dismissal.

Factors justifying that dismissal included the presence in Scotland of evidence relating to the injury, the inabihity of the defendants to implead the estate of the pilot and the British corporations responsible for maintenance and servicing of the aircraft, the burdensone nature of filing independent claims for indemnity or contribution, ${ }^{32}$ the court's lack of

26. Id. at 344,347 .

27. Id. at 343, 347. But see Braten Apparel Corp. v. Bankers Trust Co., 259 S.E.2d 110 (S.C. 1979) (although the cause of action arose in South Carolina, the suit was dismissed pursuant to a forum non conveniens motion when 12 related litigations were pending in New York, when key witnesses and parties were not subject to process in South Carolina, and when extensive pretrial litigation had already produced volumes of evidence located in New York; moreover, the plaintiff was not a South Carolina citizen).

28. 454 U.S. 235 (1981).

29. Jurisdiction over at least the propeller manufacturer was unauthorized by California law, acccording to the district court in which suit was initially filed, but jurisdiction over both manufacturers was proper in Pennsylvania. Reyno v. Piper Aircraft Co., 479 F.Supp. 727, 729 (M.D.Pa. 1979). With respect to Piper, personal jurisdiction was not an issue: Piper was a Pennsylvania corporation, and the claim against it arose out of its continous activities in the forum. Jurisdiction over the Ohio defendant was presumably proper because of its use of a stream of commerce that included the forum for the sale of the particular propeller at issue, see cases cited infra note 41; furthermore, it may have solicited Piper's business in the forum.

30. 479 F. Supp. at 727.

31. Reyno v. Piper Aircraft Co., 630 F.2d 149 (3d Cir. 1980).

32. But see Olympic Corp. v. Societe Generale, 462 F.2d 376 (2d Cir. 1972) (refusal to dismiss on grounds of forum non conveniens, where defendant's primary concern is to have both the claim 
familiarity with Scottish law, and the interest of Scotland in the litigation. ${ }^{33}$ On the other hand, several factors weighed against dismissal. The claims against the manufacturers were based upon a theory of strict hability; all of the evidence respecting that liability was in the United States, where the product was manufactured, ${ }^{34}$ and the foruin would use the law of the manufacturing site to determine that liability. In any event, Scottish law would not present particular problems for the court. Principles of res judicata would prevent the unfairness of inconsistent verdicts.

The major thrust of the Supreine Court opinion was two-fold: first, that the possibility of a less-favorable body of substantive law governing is not a controlling or even substantial factor in the analysis, which focuses instead upon issues of convenience; and second, that the strong presumption in favor of the plaintiff's choice of foruin is less forceful when the real parties in interest are foreign, since the absence of those parties from the forum weakens the presumption that the chosen forum is a convenient one. ${ }^{35}$

Even accepting the correctness of both doctrinal points, ${ }^{36}$ the case seems wrongly decided. Scotland may have been a marginally more convenient forum because of the ability of Piper to implead Scottish defendants, but certainly the burden of defending at the manufacturing site which was also Piper's state of incorporation, was in no sense "heavy," nor was the choice of that forum unsupported by "specific reasons of convenience." 37 The relationship between the defendants' activities in the forum and the claims brought there properly sustained personal jurisdiction. It is their activities in the United States that the defendants must justify, activities in which the defendants intentionally engaged and to which the defendants could reasonably have expected forum law to apply. Moreover, the Supreme Court did not dispute the propriety of an assertion of prescriptive jurisdiction by the forum over Piper, and such an assertion is justified by the undoubted interest of a state in regulating

against it and its claim against a third-party defendant tried together and where the claim against the third-party had been dismissed in the instant proceeding but where it was unlikely, given the nature of the legal issues, that separate trials would produce inconsistent results).

33. Piper Aircraft, 454 U.S. at 259-60.

34. Id. at 257.

35. The contrary argument is made in Note, Forum Non Conveniens and Foreign Plaintiffs in the Federal Courts, 69 GEO. L.J. 1257 (1981).

36. The Piper court restricted its analysis of the interests served by the doctrine of forum non conveniens to those of "convenience," that is to Gilbert's "private factors." See supra note 3. The second set of systemic interests used in Gilbert, the "public factors", which ought to be considered in the context of prescriptive jurisdiction, see infra Part II, are ignored. This can be expained by the fact that the plaintiffs in Piper did not argue that the requested dismissal would impair the interest of the forum in regulating manufacturers but rather that it would impair the plaintiffs' interests in an easier recovery.

37. Piper Aircraft, 454 U.S. at 249. 
manufacturing within its borders. ${ }^{38}$ The concerns of forum non conveniens, therefore, had already been addressed, and the plaintiffs should have been allowed to proceed in the Pennsylvania district court. ${ }^{39}$

Jurisdiction is also proper if the activity of the defendant in the forum is not continuous and the clain against him arises out of his single act in the forum. ${ }^{40}$ Such a case ought not to be dismissed on grounds of forum non conveniens. The defendant will have purposefully availed himself of the benefit of conducting activities in the forum, the sovereign will have a clear interest in regulating the conduct at issue, and most of the evidence of, and witnesses to, the conduct will likely be present in the jurisdiction. Any suit based upon the commission of a tort in the forum falls into this category, as do many claims for breach of contract. ${ }^{41}$

Of course, to the extent that jurisdiction is predicated not upon actual related activity by the defendant in the forum, but rather upon activities outside the forum that cause tortious injury therein, the connection between the defendant, the hitigation, and the forum is weakened, and argunients concerning the convenience of an alternative forum are correspondingly strengthened. Due process in this context is satisfied if

38. See generally, Part II, Section B, infra. The Court might also have taken into account the interest of Scotland in locating the litigation there in its forum non conveniens analysis. The Supreme Court's opinion did not emphasize this, however, and on these facts, the interest was not particularly weighty. Scottish law would not have permitted recovery on a theory of strict liability, but since the corporate defendants were not Scottish, the policies underlying that decision were not impaired by permitting recovery. There may be an interest in having the community in which the deaths occurred "see justice being done," but that interest alone should not sustain the forum non conveniens dismissal and is, in any event, offset by the choicc of the real parties in interest to litigate in the United States forum.

39. See Beatrice Foods Co. v. Proctor \& Schwartz, Inc., 309 Pa. Super. 351, 455 A.2d 646 (Pa. Super. 1982). But see Ahmed v. Boeing Co., 720 F.2d 224 (1st Cir. 1983); Stein, supra note 18, at 843.

40. According to International Shoe, jurisdiction is dependent here upon the quality and nature of the defendant's act in the forum and the circumstances of its commission. 326 U.S. 310, 318 (1945). As a practical matter, if a defendant acts purposefully in the forum and is sued there for damages allegedly resulting from that act, jurisdiction is undisputed. Only if the defendant was never physically present in the forum does this International Shoe category create difficulty. The Court has identified only two situations where jurisdiction is proper over a defendant who has not been physically present in the forum: first, when the defendant places its product in a "stream of commerce" thereby entering the forum and subsequently causing injury and, second, when the defendant intentionally targets a forum as the state to be affected by its activities outside the forum. World-IVide Volkswagen Corp. v. Woodson, 444 U.S. 286 (1980); Caldor v. Jones, 104 S. Ct. 1482 (1984).

41. See, e.g., Gates Learjet Corp. v. Jensen, 743 F.2d 1325 (9th Cir. 1984) (upholding personal jurisdiction in suit arising out of a distributorship agreement between an Arizona manufacturer and a Phillippine corporation and reversing a dismissal based upon forum non conveniens); Overseas Programming Co. v. Cinematographische Commerz-Anstalt, 684 F.2d 232 (2d Cir. 1982) (reversing forum non conveniens dismissal because the contractual rights of the plaintiff were to be determined in part under New York law, implying that those rights, to at least some extent, were generated by activities in the forum). But see DeShane v. Deere \& Co., 747 F.2d 1194 (8th Cir. 1984) (upholding the forum non conveniens dismissal of a claim by a Canadian plaintiff injured in Canada by a product manufactured by the defendant in the forum). 
the defendant has utilized a "stream of commerce" to obtain a wider market for its goods or publications and if, after purchase by a consumer in a forum that is part of the stream, injury results. ${ }^{42}$ Presumably, evidence with respect to injury will be centered in the forum, which will have an interest in protecting its residents from harm and which may well use its own law to determine liability. Evidence with respect to the nature of the defendant's activities will be elsewhere, however, and the forum in which those activities took place also has an interest in governing the acts of its residents. Nonetheless, the facts tyimg the defendant and the claim to the forum that are sufficient to sustain jurisdiction should also be sufficient to defeat a forum non conveniens motion. ${ }^{43}$

\section{B. Claims Not Arising Out of Defendant's Activities in the Forum}

\section{Introduction}

If a defendant has engaged in only a single or occasional act in the forum, and if the claim against him is unrelated to that act, personal jurisdiction is not justifiable on the grounds of "minimum contacts." 44 Nevertheless, historically plaintiffs in two situations have been able successfully to serve process upon such a defendant.

First, personal service of process upon a defendant present in the forum ${ }^{45}$ has always been sufficient to sustain jurisdiction, no matter how fortuitous or momentary the defendant's presence, because it is clear that the forum, at the moment of service, has power over the person of the defendant. ${ }^{46}$ Second, traditionally the seizure of property belonging to the defendant in the forum permitted the assertion of in rem or quasi in rem jurisdiction. Such seizure, in conjunction with notice to the defendant of the seizure and the claim, justified jurisdiction over the property, even when the claim against its owner had no connection to the property. Again, the justification revolved around the undisputed power of the forum over the thing seized. ${ }^{47}$

In these two situations the existence of jurisdiction over the defendant alone rarely triggers the application of forum law or ensures that the forum is a convenient one. It is not surprising, then, that the doctrine of forum non conveniens originated in admiralty, where seizure of a vessel

42. See supra note 40.

43. See Founding Church of Scientology v. Verlag, 536 F.2d 429 (D.C. Cir. 1976).

44. International Shoe Co. v. Washington, 326 U.S. 310, 316-18 (1945).

45. The concept of "minimum contacts" jurisdiction presupposes that the defendant has not been personally served with process while in the forum. Id. at 316 ("[D]ue process requires only that in order to subject a defendant to a judgment in personam, if he be not present within the territory of the forum, he have certain minimum contacts with it ....") (emphasis added).

46. See Pennoyer v. Neff, 95 U.S. 714, 734-35 (1877).

47. Id.; see also Pennington v. Fourth National Bank, 243 U.S. 269 (1917); Harris v. Balk, 198 U.S. 215 (1905). 
was the usual method of asserting jurisdiction. ${ }^{48}$

Today the seizure of a defendant's property is msufficient to sustain jurisdiction; the plaintiff must demonstrate the existence of minimum contacts. Although the presence of the defendant's property in the forum provides some contact between the defendant and the state, the sufficiency of that contact is not to be presumed. ${ }^{49}$ If power over the defendant's property alone is now insufficient to sustain jurisdiction, then power over the defendant's person based upon his presence in the forum at the time of personal service of process should also be insufficient. Thus, jurisdiction over the defendant should be denied if the claim against the defendant is unrelated to his momentary presence or to the presence of his property.

A more difficult situation arises when the defendant is engaged in continuous and systematic activity $\mathrm{m}$ the forum but the claim brought there against him is unrelated to that activity. It is in such a case that courts most frequently find that personal jurisdiction is proper, that the law of another forum ought to be apphed, and that the case should be dismissed on the grounds of forum non convemens.

The classic Supreme Court forum non conveniens case, Gulf Oil Corp. v. Gilbert, ${ }^{50}$ involved precisely such facts. The defendant, Gulf Oil, was licensed to do business in New York where plaintifs brought suit in federal district court. ${ }^{51}$ The claim involved activities of the defendant in Virginia, and Virginia law would be applied to the suit. Finding that the suit should be tried in Virginia, the Supreme Court approved the district court's dismissal. ${ }^{52}$ The Court already had imdicated in another case that, when the claim is "entirely distinct" from a defendant's continuous and systematic activities, personal jurisdiction may or may not be proper, depending upon the substantiahty and nature of the defendant's activities in the forum..$^{53}$ Given the "out" of forum non conveniens, however, courts have too often failed to consider the substantiality and nature of the defendant's contacts. If the jurisdictional analysis were properly undertaken, use of the common law doctrine would no longer be necessary to assure a convenient forum.

48. See generally Bickel, The Doctrine of Forum Non Conveniens as Applied in the Federal Courts in Matters of Admiralty, 35 CORNELl L.Q. 12 (1949); Blair, The Doctrine of Forum Non Conveniens in Anglo-American Law, 29 CoLUM. L. Rev. 1 (1929).

49. Shaffer v. Heitner, 433 U.S. 186, 207-08 (1977).

50. 330 U.S. 501 (1947).

51. The defendant's business license may be assumed to evidence a continuous and systematic business relationship between the defendant and the state.

52. 330 U.S. at 509-12.

53. International Shoe Co. v. Washington, 326 U.S. 310,318 (1945). 


\section{Jurisdiction Based on Power}

When the Supreme Court first tied due process to the existence of jurisdiction over the defendant, it held that jurisdiction was proper if, but only if, the defendant was so situated that the forum had actual control over him by virtue of its sovereign power. ${ }^{54}$ By analogy to the jurisdiction then recognized to be appropriately exercised by nation states, if the defendant was physically present in the forum at the time of service of process upon him, if his property im the forum was seized at the commencement of the suit, if he was a resident of the forum, or if his civil status under the law of the forum was at issue, jurisdiction would be sustained. ${ }^{55}$ In each of these situations, the assertion of jurisdiction does not intrude upon the sovereignty of any other (nation) state, and, theoretically, the authority of no other (nation) state is necessary to enforce any judgment agamst the defendant. Similarly, if the defendant consented to the assertion of jurisdiction over him, there would be no reason for another (nation) state to be concerued with the forum's wielding of authority and no need to involve another (nation) state in the enforcement of a judgment.

Such concern with physical control over the defendant may make perfectly good sense when the interested fora are nation states, not bound together by any common allegiance. An attempt by one nation to reach into another's territory for any reason, including the removal from that territory of an imdividual defendant, could precipitate more than mere verbal conflict. Additionally, it may be unrealistic to suppose that another nation will enforce a foreign judgment if the forum that rendered the judgment is incapable of doing so. In that event, it is systemically unwise to issue the judgment, both because it is a waste of judicial resources and because it fosters the appearance of helplessness, perhaps leading to a lack of respect for the law itself.

Neither of these concerus, however, is a problem within the United States today. It is fictitious to assume that armed conflict between states could erupt because of the exercise by one state of jurisdiction over a defendant. More importantly, the full faith and credit clause compels each state to recogmize and enforce the judgments of sister states. ${ }^{56}$ The authority or physical power of the rendering state alone does not secure enforcement of its judgments. Rather, that authority is supplennented by the federal sovereign's command to the forum's sister states, so that the authority and power of all are available to bolster the one. ${ }^{57}$ Although

54. Pennoyer v. Neff, 95 U.S. 714 (1877).

55. Id. at $722-24$.

56. U.S. CONST. art. IV, $\S 1$.

57. See generally Kurland, The Supreme Court, the Due Process Clause and the In Personam Jurisdiction of State Courts-From Pennoyer to Denckla: A Review, 25 U. CHI. L. REv. 569 (1958). 
the full faith and credit clause only requires enforcement of those judgments rendered in accordance with due process, the rendering forum itself may not enforce a judgment that fails to comply with due process. There is thus no valid reason to equate the concerns of the due process clause with the power of the forum, a fact recognized by the acceptance of "minimum contacts" as a basis for jurisdiction. Nor is there any valid reason to assume that the actual concerns of that clause-the fair and orderly administration of the laws ${ }^{58}$-are fostered simply by virtue of the existence of physical power over the defendant. Indeed, that power itself is irrelevant; only the facts that give rise to it speak to whether its exercise in a given situation would be fundamentally fair.

Today, "seizure" of the defendant's person and, in admiralty, "seizure" of a defendant's property continue to provide a basis for the assertion of jurisdiction. Both of these exercises of jurisdiction are based solely on power and should now be rejected.

If a defendant is personally served with process while in the forum, it is beyond dispute that the forum has physical control over her which could theoretically be mamtained until she comphes with any judgment rendered against her. That fact, however, does not mean that the public interest in the efficient allocation of judicial business or the valid interests of the parties would be served by the assertion of jurisdiction. If the plaintiff's cause of action arose outside the forum, those interests, in fact, would be actively harmed. At least one other forum would have a systemic interest in having the litigation brought there, and the chosen forum would have no interest in the hitigation that would justify the expenditure of its resources in resolving the dispute. ${ }^{59}$ The interests of the parties and witnesses in the expeditious resolution of that dispute would not be served if the hitigation is pursued in a forum whose only contact is its fortuitous, momentary power over the defendant. The logic of every Supreme Court opinion since 1945 compels the conclusion that such power alone is insufficient to satisfy the demands of due process. ${ }^{60}$

58. International Shoe Co. v. Washington, 326 U.S. 310,319 (1945).

59. This assumes, of course, that the plaintiff does not live in the forum.

60. For a clear exposition of this argument, see Von Mehren and Trautman, Jurisdiction to Adjudicate: A Suggestcd Analysis, 79 HARV. L. REv. 1121 (1966). Unfortunately, this argument has been rejected by assorted courts, although the United States Supreme Court has as yet not directly addressed the issue. Amusement Equip., Inc. v. Mordelt, 779 F.2d 264 (5th Cir. 1985); see, e.g., Donald Manter Co. v. Davis, 543 F.2d 419 (1st Cir. 1976): “Any legitimate showing a defendant may make as to fairness in this [jurisdictional] regard is fully cognizable under the change of venue statute, 28 U.S.C. $\$ 1404$ (a), without impinging on an established principle of jurisdiction." Id. at 420. In the context of federal court jurisdiction, the problem raised by such a cavalier dismissal of an argument based on the appropriate definition of due process may be relatively unimportant. The constitutionality of the federal sovereign's assertion of jurisdiction over one of its citizens is arguably always proper under the due process clause. However, when the subject matter jurisdiction of the federal court is based upon diversity of citizenship, as it was in Davis, at least two circuits have indicated that the current restraint embodied in FED. R. CIV. P. 4(e) is constitutionally necessary. 
The clearest expression by the Court of the irrelevance of power per se to the issue of jurisdiction came in 1977 in Shaffer $v$. Heitner. ${ }^{61}$ The defendants owned property, located in Delaware, which was sequestered at the time the complaint against them was filed. The Court was willing to assume that the forum had the kind of power over the defendants' assets that, in the past, would have assured jurisdiction, at least up to the value of those assets, on any cause of action. However, the Court recognized for the first time that jurisdiction over a res was the functional equivalent of jurisdiction over the interest of the owner in that res, and thus over the owner. The Court concluded that physical control of the res should be rejected as a basis of jurisdiction and held that "all assertions of state court jurisdiction must be evaluated according to the standards set forth in International Shoe and its progeny."62

Lower courts have not seized upon that language to reject jurisdiction based upon personal service of process within the forum. However, for the most part Shaffer has sounded the death knell of jurisdiction based upon seizure of property without an evaluation of the contacts which the presence of such property represents between the defendant and the forum. The lone hold-out has come in the context of admiralty law.

Suits in admiralty are brought against either a personal defendant, such as a shipowner, or against a ship itself. In the former case, traditionally any property belonging to the defendant has been amenable to seizure in order to secure jurisdiction in the forum. ${ }^{63}$ In the latter case, the vessel itself has traditionally been subject to seizure when it enters the forum, and such seizure has provided the necessary jurisdiction. ${ }^{64}$ Both

Securities Investor Protection Corp. v. Vigman, 764 F.2d 1309, 1315 (9th Cir. 1985); Johnson Creative Arts, Inc. v. Wool Masters, Inc., 743 F.2d 947, 950 (1st Cir. 1984). And, of course, to rcly upon forum non conveniens to remedy an unfair assertion of state court jurisdiction impliedly affirms a definition of due process based upon power, which is simply incorrect.

61. 433 U.S. 186 (1977).

62. Id. at 212.

63. Of course, such seizure of the defendant's property, which results technically in quasi in rem rather than personal jurisdiction, is not the only way in which a plaintiff may obtain jurisdiction when his cause of action is against an individual defendant. Contacts between such a defendant and the forum are frequently found sufficient to sustain jurisdiction without the attachment of property. In this case assertion of jurisdiction is proper. See infra note 76 and Section $B$ (2) Part I.

64. See generally G. Gilmore \& C. BLACK, The LAW OF AdMIRALTY 18-31 (2d ed. 1975), and F. Maraist, Admiralty IN A NutShell (1983).

Gilmore and Black point out that, unlike the English rule, American admiralty law maintains a clear jurisdictional distinction between the two proceedings. An action in rem against the vesse] does not entitle the plaintiff to proceed in personam against the vessel's owner, and jurisdiction over the owner remains dependent upon general personal jurisdiction rules. G. GILMORE AND C. BLACK, supra, at 624, 801-05; see also F. MARAIST, supra, at 338-44 (briefly discussing the effect of Shaffer, as well as cases dealing with the need for notice before being deprived of property, on seizures of vessels in both in rem and quasi in rem actions); Note, Has Shaffer v. Heitmer Been Lost at Sea?, 46 LA. L. REV. 141 (1985). 
actions have continued after Shaffer and should now be rejected.

When suit is brought against the individual defendant, seizure of that defendant's property in the forum in order to assert jurisdiction is precisely what the Shaffer Court rejected. ${ }^{65}$ The fact that the suit sounds in admiralty rather than at law or in equity does not logically change the due process analysis. The presence of the defendant's property in the forum is indeed a contact between the defendant and the forum, but it is not necessarily a sufficient one. In admiralty, as at law, the traditional justification for jurisdiction over a defendant based upon the seizure of its property in the forum has been the interest of the plaintiff in identifying a forum in which jurisdiction can be asserted and in being assured that, if judgment is rendered in the plaintiff's favor, the judgment will be paid. But neither of these interests is unique to admiralty plaintiffs, ${ }^{66}$ neither speaks to the relationship between the defendant, the litigation, and the forum, ${ }^{67}$ and neither was sufficient outside the admiralty context to sustain jurisdiction in Shaffer.

While identifying an appropriate forum by reference to contacts between it and the defendant surely is a more difficult undertaking than locating physical property belonging to the defendant, it is an undertaking necessary to due process. If the forum's assertion of jurisdiction is proper, the full faith and credit clause guarantees enforcement of its judgment against a United States defendant; if the defendant is an alien and the plaintiff demonstrates to the court a justifiable fear that its judgment would not be paid, seizure of the defendant's property to secure enforcement may well be proper. But such seizure ought not form the basis of jurisdiction.

When suit is brought against the vessel itself, seizure of that vessel is analogous to the personal service of process on an individual defendant in the forum. There is an obvious contact between the defendant and the forum, but it may not be related to the claim and may not be sufficient

65. See DeMateos v. Texaco, 562 F.2d 895 (3d Cir. 1977), cert. denied, 435 U.S. 904 (1978), which acknowledged the impact of Shaffer on admiralty law. In DeMateos, a vessel belonging to the Panamanian corporate owner of a second vessel, upon which a seaman had been injured, was attached pursuant to Pennsylvania's Foreign Attachment Rules in order to secure jurisdiction over the corporation in a suit filed in the Eastern District of Pennsylvania. Presumably in order to secure release of the vessel, counsel stipulated to service of process. The circuit court commented that "[t]hat stipulation antedated . . . the Supreme Court's endorsement . . . of our view that quasi-in-rem jurisdiction to adjudicate is subject to the same due process limitations as in personam jurisdiction." Id. at 898. Thus, it was the timing, not the theory, which sustained the "consent."

66. But see Perusahaan Umum Listrik Negara Posat v. M/V Tel Aviv, 711 F.2d 1231, 1236-38 (5th Cir. 1983).

67. Precisely the lack of such contacts results in dismissals under the doctrine of forum non conveniens when such quasi in rem jurisdiction is asserted and accepted without question. See, e.g., Canada Malting Co. v. Paterson Steamships, 285 U.S. 413 (1932); Yerostathis v. A. Luisi, Ltd., 380 F.2d 377 (9th Cir. 1967). 
under International Shoe to sustain jurisdiction. ${ }^{68}$ The presence of the vessel upon which a cause of action arose may mean that essential evidence is also present in the forum, or it may not, depending upon the nature of the claim, the current presence or absence of crew witnesses, and other factors. ${ }^{69}$ The theoretical defendant is the vessel, but the party with the real interest in the litigation is obviously its owner, and due process demands the same consideration of contacts in this context as in any other.

In the absence of contacts between the real defendant, the litigation, and the forum, concerns about the fairness of jurisdiction have been answered by reference to the doctrine of forum non conveniens. For example, in Trans-Asiatic Oil Ltd. S.A. v. Apex Oil Co. ${ }^{70}$ the court explicitly relied on forum non convemiens (as codified at 28 U.S.C. $\S 1404$ ) to avoid a jurisdictional defense. A Missouri corporation was sued in the district court of Puerto Rico. Jurisdiction over it was based upon the attachment of a debt owed by the corporation to a Puerto Rican entity, pursuant to Rule B of the Suppleinental Rules for Certain Admiralty and Maritime Claims of the Federal Rules of Civil Procedure. The defendant challenged the attachment as a violation of Shaffer as well as of its constitutional right to notice. ${ }^{71}$

68. Such jurisdiction is, of course, technically an assertion of in rem jurisdiction, which was not destroyed by Shaffer. Nevertheless, the issues presented by these admiralty claims parallel those presented by actions in personam, rather than those presented by actions in rem, which generally adjudicate title to the res as against the world. Furthermore, although Shaffer seemed to indicate that certain kinds of in rem jurisdiction might survive, jurisdiction in these cases might well be proper as well on the basis of the International Shoe analysis. For example, the permanent location of the res in the forum, as well as the forum's interest in the marketability of property within its borders, may strengthen the contacts reflected by the presence of res between the forum and the real party in interest. See generally J. Friedenthal, M. Kane \& A. Miller, Civil, Procedure 15156 (1985).

69. See, e.g., Perusahaan Umum Listrik Negara Pusat v. M/V Tel Aviv, 711 F.2d 1231 (5th Cir. 1983) (Indonesian and Israeli vessels collided in the Straits of Gibraltar; only contact with United States was seizure of Israeli ship in port of Houston two and one-half years after the collision; forum non conveniens dismissal affirmed); Veba-Chemie A.G. v. M/V Getafix, 711 F.2d 1243 (5th Cir. 1983) (vessel seized in Louisiana; accident occurred on the high seas; all evidence and witnesses in the Netherlands; dismissal on the grounds of forum non conveniens affirmed); Anastasiadis v. S.S. Little John, 346 F.2d 281 (5th Cir. 1965) (forum non conveniens dismissal affirmed even though alleged breach of contract and tort occurred in Texas, where vessel was seized, and beneficial owner of vessel was a United States citizen; the vessel's presence was transitory, the plaintiff was a Greek citizen, and the contract called for the use of Greek law and courts), cert. denied, 384 U.S. 920 (1966). Compare Gkiafis v. Steamship Yiosonas, 387 F.2d 460 (4th Cir. 1967) (reversing a lower court's dismissal of three general maritime claims, the court focused on the kind of contacts frequently used to sustain in personam jurisdiction; only the dissenting judge found it relevant that those contacts did not give rise to the plaintiff's claims). See Part II, Section $B(2)$, infra.

70. 743 F.2d 956 (1st Cir. 1984).

71. Sniadach v. Family Finance Corp., 395 U.S. 337 (1969) (state statute which failed to provide notice and an opportunity to be heard beforc garnishment violated due process). As of August 1, 1985, Rule B was amended to require judicial participation in the attachment, in an attempt to obviate the Sniadach problem. 28 U.S.C. Supplemental Rules for Certain Admiralty and 
Of course, the assertion of jurisdiction over a United States corporation in any federal court may raise no constitutional problem, ${ }^{72}$ and had the court upheld jurisdiction by analogy to statutes permitting rationwide service of process, the basis of attack would have presumably been the validity of the analogy. In fact, however, the court analyzed the defendant's Shaffer argument on the merits. It stated that the reason for requiring minimum contacts was two-fold: first, to protect the defendant from the burden of litigating in an inconvenient and distant forum, and second, to restrain a state from impinging upon tlie sovereignty of sister states. Finding that the second concern was inapposite in the federal courts, the opimion held that the first concern was "properly addressed by the nonconstitutional doctrine of forum non conveniens as codified at 28 U.S.C. $\S 1404$ (1982)."73 Although it is true that that statute is applicable in admiralty, ${ }^{74}$ the court failed to explain why it operates to make a due process argunient irrelevant. ${ }^{75}$

Presumably, if the defendant, or the owner of the defendant-vessel, will actually be severely inconvenienced by the assertion of jurisdiction, the court will dismiss the suit under the doctrine of forun1 non conveniens, and all will be as it would have been had tlre court rejected jurisdiction based upon power. But a common law doctrine is not a practical or theoretical answer to a constitutional problen1. In the first place, the litigation proceeds differently depending upon which theory is enıbraced. It is the plaintiff's burden to denonstrate jurisdiction. If contacts are required, it is thus for the plaintiff to prove them. It is the defendant's burden to demonstrate that dismissal on the grounds of forum non conveniens is appropriate, ${ }^{76}$ however, and courts stress that this burden is a

Maritime Claims of the Federal Rules of Civil Procedure. But see Schiffahartsgesellschaft Leonhardt v. A. Bottachi, 773 F.2d 1528 (11th Cir. 1985).

72. See supra note 60.

73. Trans-Asiatic Oil, $743 \mathrm{~F} .2 \mathrm{~d}$ at 959.

74. Continental Grain Co. v. Barge FBL-585, 364 U.S. 19 (1960).

75. See also Olympic Corp. v. Societe Generale, 462 F.2d 376, 378 (2d Cir. 1972); Latimer v. S/A Industrias Reunidas F. Matarazzo, 175 F.2d 184 (2d Cir.), cert. denied, 338 U.S. 867 (1949); Kilpatrick v. Texas \& Pac. Ry. Co., 166 F.2d 788 (2d Cir.), cert. denied, 335 U.S. 814 (1948); McCarthy v. Canadian Nat'l Rys., 322 F. Supp. 1197 (D. Mass. 1971).

76. See, e.g., Insurance Co. of N. Am. v. Marina Salina Cruz, 649 F.2d 1266 (9th Cir. 1981). In discussing the burden placed upon the defendant Mexican shipyard by locating the litigation in Alaska, where a vessel insured by the plaintiff had sunk, the court noted that witnesses and documents were primarily located in Mexico and that translations would be necessary. It then went on to comment:

It is, of course, true that many of the inconvenience burdens in this case are symmetrical. ... The law of personal jurisdiction, however, is asymmetrical. The primary concern is for the burden on a defendant. If the burdens of trial are too great for a plaintiff, the plaintiff can decide not to sue or, perhaps, to sue elsewhere. A defendant has no such luxury. The burdens on a defendant are of particular significance if, as here, the defendant has done little to reach out to the forum state.

Id. at 1272 (citation omitted).

Had the court focused on difficulties of translation in the context of forum non conveniens, its 
heavy one. ${ }^{77}$ If jurisdiction is premised on contacts, the forum non conveniens notion should fail, ${ }^{78}$ but if jurisdiction is premised on power, the motion will not inevitably prevail. ${ }^{79}$ More importantly, dismissal on the

doctrinal bias and, therefore, the weight which it gave to the same facts would presumably have shifted. Forum non conveniens is also an asymmetrical doctrine, but it begins with the assumption that, since other constraints on a system's authority have not been violated, the chosen forum is appropriate; its bias is in favor of the plaintiff's choice.

77. The burden on the defendant in admiralty cases may be heavier than that imposed generally under Gulf Oil Corp. v. Gilbert, 330 U.S. 501 (1947). See, e.g., Poseidon Schiffahrt, G.M.B.H. v. M/S Netuno, 474 F.2d 203, 204 (5th Cir. 1973) (in admiralty, jurisdiction should be exercised unless the defendant can establish that to do so would work an injustice, as opposed to determining if, on balance, injustice would result if jurisdiction was not exercised) (citing The Belgenland, 114 U.S. 355 (1885)); Perusahaan Umum Listruk Negara Pusat v. M/V Tel Aviv, 711 F.2d 1231，1236 (5th Cir. 1983) (the admiralty rule is not actually an exception to the Gilbert standard; rather, the in rem nature of admiralty proceedings adds to the normal presumption in the plaintiff's favor because of the increased difficulty it places on the defendant of locating an adequate alternative forum).

That burden is theoretically only increased if jurisdiction is based upon seizure of property within the forum. If, for example, quasi in rem jurisdiction has been obtained by such seizure, any alternative forum must be able to provide similar security with respect to enforcement of a judgment. This can be achieved however, by the defendant's stipulation. If the claim is against the vessel itself, the defendant must show that the claim may proceed against that vessel elsewhere, and a failure to do so will result in a denial of dismissal. See Tramp Oil \& Marine, Ltd. v. M/V Mermaid I, 743 F.2d 48 (1st Cir. 1984). Of course, there is no good reason why stipulation cannot cure this defect as well. Indeed, such consent was specifically held sufficient in Veba-Chemie A.G. v. M/V Getafix, 711 F.2d 1243 (5th Cir. 1983). The court there rejected the plaintiff's argument that an alternative forum was only "available" if the defendant had been subject to scrvice there at the time the suit was instituted-a physical impossibility if the claim is against a specific vessel and jurisdiction is predicated upon the vessel's presence at the time of service. An analogy to 28 U.S.C. $\S 1404$, as interpreted in Hoffman v. Blaski, 363 U.S. 335 (1960), was not convincing: $\$ 1404$ transfers require a lesser showing of inconvenience than do forum non conveniens dismissals (here the court cited Norwood v. Kirkpatrick, 349 U.S. 29 (1955)), and the process restriction imposed by Hoffman offsets that leniency. Additionally, $\$ 1404$ operates differently than does forum non convenicns in other contexts, and the analogy requested would involve the district court in complex questions of foreign jurisdictional law. See Veba-Chemie, 711 F.2d at 1246-48.

78. There are, of course, occasional cases in which the court finds that the claim is related to purposeful acts in the forum but that, nonetheless, forum non conveniens dismissal is or may be appropriate. See, e.g., In re Oil Spill by Amoco Cadiz, 699 F.2d 909, 916 (7th Cir.), cert. denied, 464 U.S. 864 (1983); J.F. Pritchard \& Co. v. Dow Chemical of Canada, 462 F.2d 998 (8th Cir. 1972). These opinions generally share two fiaws. First, considerations of ease of litigation which ought to be treated in a jurisdictional context are relegated entirely or in major part to the forum non conveniens analysis. Second, and more importantly in light of the relationship between related purposeful action and such considerations, the courts fail to distinguish between actions of the defendant in the forum from which the claim arises and actions which form part of the relationship between the parties but which are not relevant to the dispute between them. See Pacific Atl. Trading Co. v. M/V Main Exp., 758 F.2d 1325 (9th Cir. 1985); Helicopteros Nacionales Colombia, S.A. v. Hall, 104 S.Ct. 1868 (1984) (Brennan, J., dissenting).

79. See, e.g., Swift \& Co. Packers v. Compania Columbiana del Caribe, 339 U.S. 684, 697-98 (1950) (forum non conveniens dismissal not appropriate when vacation of an attachment would deprive a United States plaintiff of security); Kloeckner Reederei und Kohlenhandel v. A/S Hakedal, 210 F.2d 754 (2d Cir.), appeal dismissed per stipulation, 348 U.S. 801 (1954) (dismissal on grounds of forum non conveniens reversed when such dismissal would not precludc a trial in London on the merits of libellants' claims and alternative forum not more convenient for all witnesses, although loss of cargo and alleged negligent acts all occurred in the English Channel). 
grounds of forum non convemiens is discretionary; dismissal for lack of jurisdiction is not. If the concerns expressed by "minimum contacts" are treated under the forum non convemiens analysis, the role of the reviewmg court is diminished, and the role of due process itself, as a constitutional limit on power, is demigrated and obscured.

The continuing acceptance by courts of jurisdiction based upon power over defendants does logically necessitate reference to some doctrine to mitigate potentially unfair results. Forum non convemens, with its focus upon the private interests of the hitigants, enables courts to avoid the worst excesses of an improper jurisdictional analysis. Nevertheless, the availability of dismissal under the doctrine of forum non convernens does not excuse continued reliance on an out-dated concept of due process.

The appropriate level of burden that a forum may place upon a defendant in liglit of the benefit it confers upon him-not power-lies at the heart of the protection afforded by due process. Recognition of this fact compels the abolition of jurisdiction based upon seizure of a defendant or lier property, im law and in admirality. Sucl abolition would drastically reduce the number of situations in which forum non convemens need be rehed upon in order to reach an equitable result.

\section{Jurisdiction Based on Contacts Unrelated to the Claim Against the Defendant}

In International Shoe Co. v. Washington, the Supreme Court coininented:

While it has been held ... that continuous activity of some sorts within a state is not enough to support the demand that the corporation be amenable to suits unrelated to that activity . . ., there have been instances in which the continuous corporate operations within a state were thought so substantial and of such a nature as to justify suit against it on causes of action arising from dealings entirely distinct from those activities. ${ }^{80}$

The clear thrust of the statement is that jurisdiction ouglit not to be asserted over a defendant inerely upon a finding of continuous activity by that defendant in the forum. Instead, it is necessary to determine the relationship between the activity and the claim, ${ }^{81}$ and if there is no relation between the two, it is necessary to determine the nature and substan-

80. 326 U.S. 310,318 (1945) (citations omitted).

81. The difference between forum activity "entirely distinct" from the cause of action and forum activity which actually gives rise to the cause of action is clear. Somewhere between the two extremes is forum activity which is part of the total relationship between the litigants but which is irrelevant to the dispute between them. For purposes of this Article, it is assumed that a "related" cause of action is one that arises out of the activities of the defendant in the forum. See supra note 78. 
tiality of the activity in order to determine the propriety of an assertion of jurisdiction.

Before turning to the multitude of cases in which courts have found undifferentiated continuous activity in the forum to be sufficient to sustam jurisdiction on an unrelated claim, two clearly defined situations should first be parsed out and discussed. If the forum chosen by the plamtiff is the only forum in which the dispute could be litigated or if the defendant is a citizen of the forum, both the jurisdictional analysis and any subsequent forum non convemiens analysis are distinct from the analyses applied in more generic fact patterns.

\section{a. Jurisdiction Based on Absence of an Alternative Forum}

A classic example of proper jurisdiction over a defendant acting contmuously in the forum but being sued on a claim unrelated to its forum activities is Perkins v. Benguet Consolidated Mining Co. ${ }^{82}$ in which the Supreme Court found no constitutional impediment to Ohio's assertion of jurisdiction. The defendant, a Philippine corporation, could not have been sued at home simce, at the time suit was filed, the United States was at war with Japan, and the Japanese occupied the Philippines. In order to provide the plaintiff with a forum, the litigation had to proceed in Ohio.

The driving concern of the courts in this context is fairness to the plamtiff. Generally, the focus of a jurisdictional analysis is on the defendant: it is the defendant's right that the due process clause protects, and, therefore, the burden that litigating in the forum places on the defendant is the cornerstone of most decisions. Consideration of the interests of the plaintiff is usually reserved for the forum non conveniens analysis. This concern usually arises when the plaintiff is a citizen of the forum. In the classic forum non conveniens analysis the plaintiff's citizenship is relevant because such citizenship implies that it is convenient to the plaintiff to continue litigation in the chosen forum. That convenience, in turn, supports the "strong presumption" in favor of the plaintiff's choice. ${ }^{83}$

82. 342 U.S. 437 (1952).

83. Piper Aircraft Co. v. Reyno, 454 U.S. 235, 255-56 (1981); see also Top Form Mills v. Sociedad Nationale Ind. Applicazioni Viscosa, 428 F. Supp. 1237 (S.D.N.Y. 1977); States Marine Lines v. The M/V Kokei Maru, 180 F. Supp. 255 (N.D. Calif. 1960); Wheeler v. Societe Nationale de Fer Francais, 108 F. Supp. 652 (S.D.N.Y. 1952); $c f$. Pain v. United Technologies Corp., 637 F.2d 775, 797 (D.C. Cir. 1980) (decided before Piper) ("[A]t best, citizenship serves as an inadequate proxy for the American residence of plaintiff, whieh in turn is only one indicator of how inconvenient it may be for the plaintiff to litigate his case in a foreign forum." (emphasis in the original)), cert. denied, 454 U.S. 1128 (1981).

The plaintiff's citizenship does not necessarily imply that the forum is a convenient one. If, for example, and as noted above, the plaintiff is a citizen but not a resident of a state or, in the federal context, if an American citizen is domiciled abroad, the continuing presence that makes the forum 
In the jurisdictional context, it is not clear how the interests of the plaintiff justify forcing the defendant to assume a greater burden than that which he has voluntarily assumed by acting in the forum. It must be remembered, however, that the lack of contacts between the defendant and the forum usually will also signify a lack of a valid forum interest in the dispute and may suggest that a competing forum has a greater interest in adjudicating the controversy. If the plaintiff is a citizen of the forum and no other foruin is available, the forum has a strong interest in permittimg the suit to proceed. If the plaintiff is not a citizen of the state, the forum's imterest is less, but there is presumably a general systemic interest in resolving legal disputes in courts of law. Finally, if suit is not possible elsewhere, it is perhaps because no other sovereign has an interest in the dispute, and an assertion of jurisdiction will, therefore, not impinge on any other system. ${ }^{84}$

The impossibility of proceeding elsewhere is more frequently not a physical problem, as it was in Perkins, but a tactical one. The competing foruin, as a matter of pohicy, may refuse to enforce the plaimtiff's claim.

presumptively convenient is lacking. Similarly, if the plaintiff's claim to be treated as a citizen is based upon a treaty provision allowing nationals of the signatories access to each other's courts on terms no less favorable than those applieable to nationals of the forum, the plaintiff's convenience is in no way served by retaining the hitigation. See Farmanfarmaian v. Gulf Oil Corp., 588 F.2d 880, 882 (2d Cir. 1978). Finally, if the named plaintiff is only one of hundreds who could potentially bring the same claim, as in a stockholder's derivative suit, the claim of convenience is "considerably weakened." Koster v. Lumbermens Mutual Co., 330 U.S. 518 (1947).

If the plaintiff is basing its action on the rights of a foreign party-as when, for example, an assignee brings its assignor's claim against a defendant-at least one court has refused to give particular weight of the assignee's citizenship. Del Monte Corp. v. Everett Steamship Corp., 402 F. Supp. 237, 243 (N.D. Cal. 1973). In this situation the actual, named plaintiff may indeed be able to litigate most conveniently in its home forum. The plaintiff's status as an assignee highlights the fact that the litigation is unrelated to the plaintiff's activities in the forum.

In Del Monte the court refused to give special weight to the plaintiff's place of incorporation. If citizenship is by virtue of incorporation, rather than of principal place of business, the "home" forum actually may not be convenient for the plaintiff. See, e.g., Texaco Trinidad, Inc., v. Astro Exito Navegacion S.A., 437 F.Supp. 331 (S.D.N.Y. 1977). Del Monte, however, had its principal place of business in California, and it is unclear why the resulting convenience to it of litigating there should be given less weight merely because it was an assignee. Nonetheless, the result is justifiable. Even in the forum non conveniens determination, citizenship-in determining the plaintiff's convenience-although clearly relevant is not determinative in the Gilbert balance. See, e.g., Mizokami Bros. of Arizona, Inc. v. Baychem Corp., 556 F.2d 975 (9th Cir. 1977), cert. denied, 434 U.S. 1035 (1978); Ionescu v. E.F. Hutton \& Co. (France) S.A., 465 F. Supp. 139 (S.D.N.Y. 1979); Silversmith v. Kenosha Auto Transport, 301 N.W.2d 725 (lowa 1981).

84. See, e.g., Hoffman v. Goberman, 420 F.2d 423 (3d Cir. 1970) (contract dispute between two United States citizens involving the stock ownership of a Netherlands Antilles corporation). In the context of forum non conveniens, the court questioned the availability of an alternative fornm, as the Netherlands Antilles may or may not accept jurisdiction in a claim between aliens. The doubt this raised added weight to plaintiffs' argument against dismissal. $7 d$. at 428 .

However, the impossibility may arise from facts unrelated to the legal interests of the parties and the fora. In Perkins itself, for example, the occupying government of the Philippines certainly had a valid interest in the standards against which its corporate entities were to be judged and the extent of their potential liability. 
This second reason for the lack of an alternative forum is irrelevant to the issue of personal jurisdiction. It speaks instead to the issue of whether the law of the chosen or the alternative forum ought to regulate the parties' conduct. ${ }^{85}$ Only in the first, Perkins situation does the inability of the plamtiff to sue elsewhere give rise to systemic interests of the chosen forum that justify jurisdiction.

When jurisdiction is based upon continuous unrelated activity by the defendant and is justified because no other forum is available, no forum non conveniens defense is possible. The sine qua non of the doctrine is an alteruative forum; ${ }^{86}$ jurisdiction is prenised on its lack. Therefore, this fact pattern causes no conflict between the doctrines; no court utilizes forum non conveniens in this situation to "correct" an improper jurisdictional decision.

\section{b. Jurisdiction Based upon the Defendant's Citizenship}

In the second distinct situation, the defendant is a citizen of the forum. Her contact with it is continuous, and by virtue of her citizenship, she claims the benefits and protections of the forum's laws. The sovereign has an obvious interest in providing a forum in which clainis against the defendant inay be heard. The phrase "so substantial and of such a nature," as used by the Supreme Court in International Shoe, ${ }^{87}$ is cryptic at best, but certainly the relationship between a citizen and her state or country is both close and unique. To permit a citizen to be sued at hoine, even on a cause of action that arose from her activities elsewhere, is to provide a plaintiff with one choice of forum that is always correct. This beconies increasingly important as other "always correct" choices, such as where the defendant may be personally served or where her property may be seized, beconie unavailable.

At first blush, it would seem that a defendant sued at home would not be able to make the kind of showing of inconvenience necessary to a forun 1 non convemens dismissal. Evidence, witnesses, and the source of applicable law might all be foreign, but the defendant is in the forunt and could hardly maintain that she is unduly burdened by being forced to defend on her "honie turf." Unfortunately, the relationship between citizenship and convenience is not so clear cut, ${ }^{88}$ and dismissals of clainis against citizens of the forum on grounds of forum non conveniens do occur. If, in fact, the doctrine currently serves no useful purpose, then either such decisions are wrong or jurisdiction based upon citizenship ought not to be always valid.

85. See infra notes $118-204$ and accompanying text.

86. Gulf Oil Corp. v. Gilbert, 330 U.S. 501, 506-07 (1947).

87. 326 U.S. 310,318 (1945).

88. See supra note 83 . 
The constitutional validity of jurisdiction based upon citizenship is beyond dispute. The contacts that citizenship represents clearly satisfy both the "fairness" and the dual "sovereignty" concerns of jurisdiction. A sovereign can confer no greater benefit than citizenship. The resulting burden of submitting to that sovereign's courts, which are, after all, part of the governing structure created and controlled by the citizens, is in no way undue. The sovereign has a strong interest in providing a foruin for redressing injuries caused by its citizens.

Furthermore, in light of the unique relationship between the forum and the citizen-defendant, the assertion of jurisdiction cannot be said to deprive another foruin with greater interest of the opportunity to resolve the dispute. Even if a citizen of another forum has been imjured, thus creating an interest in that other forum in protecting its citizens, the initial choice between fora is the plaintiff's. Whatever generalized, as opposed to protective, interest another forum may have in governing conduct within its borders is an issue best addressed in the prescriptive jurisdiction inquiry.

As currently understood, the doctrine of forum non conveniens might nonetlieless permit dismissal of the plaintiff's claim, presumably compelling its reinstitution in the forum wlere the cause of action arose. This result is inost appealing when a corporate defendant is sued in the state of its incorporation, and the corporation has no other contacts with that state. ${ }^{89}$ The plaintiff ordinarily wislies United States law to govern. The court's rejection of that arguinent paves the way for its dismissal of the suit. ${ }^{90}$

As a tactical matter, it is difficult to see why a plaintiff would continue to prefer a forum far removed froin the situs of the dispute once the court has rejected the argument that the forum's substantive law sliould govern. ${ }^{91}$ Nevertheless, that choice should remain the plaintiff's. Con-

89. See, e.g., Dahl v. United Technologies Corp., 632 F.2d 1027 (3d Cir. 1980) (upheld dismissal on forum non conveniens grounds of wrongful death suit by representatives of Norwegian decedents who died in a Norwegian-owned-and-operated helicopter in Norwegian territorial waters brought against American manufacturers).

90. See, e.g., Needham v. Phillips Petroleum Co. of Norway, 719 F.2d 1481 (10th Cir. 1983); Dahl v. United Technologies Corp., 472 F. Supp. 696 (D. Del. 1979), aff'd, 632 F.2d 1027 (3d Cir. 1980). In Needham, even jurisdiction was questionable; the defendant was incorporated in Delaware and had its principal place of business in Norway, but was sued in an Oklahoma district court. Oklahoma was the principal place of business of Phillips Petroleum Co., the parent of the defendant.

91. Plaintiffs presumably perceive procedural advantages to litigating in a United States forum, although the argument is rarely raised or discussed directly. See, e.g., Del Rio v. Ballengcr Corp., 391 F. Supp. 1002 (D.S.C. 1975) (suit arising out of Panamanian car accident dismissed by Canal Zone court for lack of personal jurisdiction over the defendant because accident did not occur in the Zone; second suit in South Carolina, home of the defendant, dismissed on grounds of forum non conveniens, the alternative forum being Panama); Domingo v. States Marine Lines, 340 F. Supp. 811 (S.D.N.Y. 1972) (Philippine plaintiffs suit on a claim arising from a ship collision in Manila Harbor against corporation with its principal place of business in New York dismissed on grounds of forum 
cerns of convenience, at the heart of the forum non conveniens motion, are, after all, nerely a reflection of the concern with the burden that litigating in the fornn would place upon the parties. One of those parties, the plaintiff, has expressed a desire to shoulder it. And the imposition of that burden upon the defendant, no matter how severe, is sustained by the benefit conferred by citizenship. Indeed, the constitutional justification which supports jurisdiction is destroyed unless the burden is seen as one voluntarily assumed by the defendant. ${ }^{92}$

Furthermore, if the defendant is a citizen of the forum, that forum is not "disimterested," in the Gilbert sense, no matter how strong the interests of the conipeting forun. It is not in any sense unfair to inipose upon the defendant's home foruin the economic burden of litigating claims brought against its citizens.

In situations in which the citizenship of a corporation is based upon the fact that the forun is its principal place of business, ${ }^{93}$ or in which an individual is both a citizen and resident of the forum, disnissals based upon foruin non conveniens contradict even inore clearly the constitutional justification underlying the assertion of jurisdiction. The burden of litigating in the forum is mitigated by the fact that that is where the defendant is, even if the action arose elsewhere. This is less clear in the

non conveniens even though defendant's sources of proof were in New York); $c f$. Mohr v. Allen, 407 F. Supp. 483 (S.D.N.Y. 1976) (suit dismissed for lack of diversity and forum non conveniens, although, with respect to the latter, defendant apparently resided in New York since venue was proper-although the cause of action arose in Mexico).

One "procedural" advantage that plaintiffs occasionally argue and that may be persuasive is that the plaintiff is financially unable to proceed in the absence of a contingent fee arrangement and that such arrangements are illegal in the alternative forum. See, e.g., Macedo v. Boeing Co., 693 F.2d 683 (7th Cir. 1982); Fiorenzia v. United States Steel Int'l, Ltd., 311 F. Supp. 117 (S.D.N.Y. 1969).

It may also be possible to convince the court that the procedures offered by the alternative forum are so clearly madequate that the forum is not actually available. See, e.g., Mobil Tankers Co. v. Mene Grande Oil Co., 363 F.2d 611 (3d Cir.), cert. denied, 385 U.S. 945 (1966); see also Piper Aircraft Co. v. Reyno 454 U.S. 335 (1981) (a remedy under foreign law may be so clearly inadequate as to be no remedy at all).

92. See, e.g., Burt v. Isthmus Development Co., 218 F.2d 353 (5th Cir.), cert. denied, 349 U.S. 922 (1955):

It must be remembered that appellee is a Texas corporation and that this suit was brought at its domicile which its incorporators chose and established. So far as we know, appellee has no other place of business in this country; surely it cannot complain of being sued at its headquarters and domicile on the ground that a major portion of its actual operations occurs elsewhere.

Id. at $357-58$ (emphasis in original).

See also Hoffman v. Goberman, 420 F.2d 423 (3d Cir. 1970); Morehead v. Barksdale, 263 F.2d

117 (4th Cir. 1959); Eaton v. Second Judicial Dist. Court, 616 P.2d 400 (Nev. 1980).

93. Technically, a corporation is a "citizen" of the state in which it has its principal place of business for purposes of determining diversity jurisdiction under 28 U.S.C. $\$ \S 1332,1441$. However, it is perfectly reasonable to assume, as courts seem to do, that the continuous activity of the corporation implicit in a finding of "principal place of business" is sufficient to sustain personal jurisdiction. 
corporate than in the individual context, since a corporation may act simultaneously in numerous fora, but it will be a rare instance in which no activity in the forum is relevant to the dispute, even if the plaintiff's claiin did not "arise out of" activities there.

Fitzgerald v. Texaco, Inc. ${ }^{94}$ although wrongly decided, provides a good exainple of this. The defendant corporation was sued in the Southern District of New York, where it had its principal place of business, by assorted foreign corporations on claims arising out of the loss of a German vessel and cargo in the Enghish Channel. The loss occurred when the vessel struck the submerged wreckage of a ship owned by a Panamanian subsidiary of Texaco, whose habihity was premised on a failure to properly mark the wreckage.

In upholding dismissal of the clain on grounds of forun non conveniens, the inajority rehed, in traditional fashion, on the presence of witnesses in England and on the mability of Texaco to miplead or subpoena the owners of the subinerged wreck or the members of Trinity House, an English entity involved in the Enghish investigation. The court was unpersuaded by either the presence of evidentiary inaterials in New York or the plaintiff's claim that the defendant had supervised the search operation froin New York, an argnment the majority characterized as supported only by "imsubstantial" evidence.95

The dissent pointed out that since the plaintiff had not been permitted to use discovery to determine the role of the defendant in the search, that characterization of the evidence was not substantiated. ${ }^{96}$ In light of the fact that the subinerged vessel was really American, in spite of its technical Panamanian registry, and that current methods of communication inevitably lessened any argued inconvemence, the dissent would have permitted suit to continue in New York. The dissent also relied on the presence of the defendant and of docuinentary evidence in New York, as well as the relative proximity of the Panainanian subsidiary, to argue that the balance of conveniences in favor of England was too slight to support the dismissal. ${ }^{97}$

\footnotetext{
94. 521 F.2d 448 (2d Cir. 1975), cert. denied, 423 U.S. 1052 (1976).

95. Id. at 450 .

96. Id. at $455 \mathrm{n} .1$.

97. Id. at 455. See also Cuevas v. Reading \& Bates Corp., 770 F.2d 1371 (5th Cir. 1985) (U.S. law not applicable and suit dismissed on the grounds of forum non conveniens, although the forum was the defendant's principal place of business and most of the cited inconvenience was to the plaintiff); Pereira v. Utah Transport Inc., 764 F.2d 686 (9th Cir. 1985) (U.S. law not applicable when only tie to the U.S. was the defendant-shipowner's principal place of business in the forum; claim dismissed on the grounds of forum non conveniens); Bailey v. Dolphin Intern., Inc., 697 F.2d 1268 (5th Cir. 1983) (after finding that U.S. law was not applicable to death upon a quasi-stationary rig in Indonesian waters [see infra note 189, and accompanying text], the court affirmed the dismissal of the claim on the grounds of forum non conveniens, although the Panamanian corporate owner of the rig and its corporate owner both had their principal place of business in Texas and although general
} 
If the defendant's principal place of business is in the forum, the theoretical interest of the forum in the litigation is the same as it is when the defendant's citizenship there is by virtue of its incorporation under the forum's law. As a practical matter, however, public interest may be greater where the defendant is perceived as "local" because of its extensive activites in the community. Thus, the same contacts that sustain jurisdiction make dismissal under forum non conveniens inappropriate. ${ }^{98}$ Convemience reflects the propriety of burdening the defendant by compelling him to hitigate in the plaintiff's chosen forum, and that burden is justified by the defendant's citizenship. To permit the defendant to escape an assertion of jurisdiction makes a mockery of the jurisdictional analysis and serves no public purpose.

\section{c. Jurisdiction Based upon the Defendant's Continuous Activity in the Forum}

Most cases that have improvidently mixed concerns underlying personal jurisdiction and those underlying forum non conveniens involve noncitizen defendants doing continuous business in the forum that is unrelated to the claim brought there. In this situation, the analytical failure most frequently involves a refusal by the court to consider the possibility that the defendant's contmuous business is not sufficiently substantial to support an assertion of jurisdiction. ${ }^{99}$ In International Shoe terminology, the "nature" of that business results in a relationship with the forum different from that forged by virtue of citizenship. ${ }^{100}$

policy regarding the rig was made there); Fajardo v. Tidewater, Inc., 707 F.2d 858 (5th Cir. 1983) (fact that defendant's principal place of business was in forum insufficient to preclude a forum non conveniens dismissal of a claim which arose in Norway).

98. Compare Akers v. Norfolk \& Western Ry. Co., 378 F.2d 78 (4th Cir. 1967), with Chicago, R.I. \& Pac. Railroad v. Igoe, 220 F.2d 299 (7th Cir. 1955). In those cases, motions to transfer the suits, pursuant to 28 U.S.C. $\$ 1404(a)$, from the defendants' principal places of business to the districts in which the claims arose were granted; indeed, in Igoe, the district court's refusal to transfer was reversed as an abuse of discretion. Arguably, those motions should have been denied, but, as pointed out supra at note 18, transfers within the same system do not raise the problems caused by reliance upon forum non conveniens. Additionally, a lesser showing of inconvenience is required to sustain such a transfer. But see Moore v. Chicago \& North W. Transp. Co., 457 N.E.2d 417 (Ill. 1983) (refusal to grant forum non conveniens dismissal an abuse of discretion, although suit was brought at the defendant's principal place of business); Mobley v. Southern Ry. Co., 4I8 A.2d 1044 (D.C. App. 1980) (granting a forum non conveniens dismissal when suit had been brought at "corporate headquarters." It is not clear from the opinion whether Washington D.C. was the defendant's principal place of business.).

99. For a relatively rare recognition of this possibility, see Johnson Creative Arts v. Wool Masters, 743 F.2d 947 (1st Cir. 1984) (analyzing the relationship between 28 U.S.C. $\$ 1391$ (1982) and personal jurisdiction).

100. For an oddly twisted recognition of the distinction between contacts that result from a defendant's continuous activity in the forum and its citizenship in the forum, see Cowan v. Ford Motor Co, 694 F.2d 104 (5th Cir. 1982). In Cowan, the court relied on a dubious "consent" theory to justify jurisdiction over a foreign corporate defendant that was sued on a cause of action unrelated to its activities within the state. The court distinguished United States Supreme Court decisions 
While it is true that in both instances the forum does confer upon the defendant operating purposefully within its borders some degree of benefit and protection, the difference in degree is qualitative as well as quantitative. The benefits of citizenship sustain any and every burden of defense; the benefits garnered by acting continuously in the forum do not-hence, International Shoe's concern with "substantiality."

Unfortunately, the term "substantiality" has never been defined. "Substantial" activity must be "substantial" with respect to something else, but what? Is the issue the percentage, for example, of a firm's profits that it derived from the forum, or the percentage of its employees located there, or the impact that it has on the forum's economy, irrespective of the importance of its activities there to its own balance sheet?

Courts routinely struggle with similar questions when attemptimg to determine a diversified corporation's primcipal place of business for purposes of diversity jurisdiction. In that context, the reason for asking the question provides a guidepost-the search is for the forum in which the corporation is least likely to be perceived as "alien" and thus im which it does not need the protection against local prejudice afforded by such jurisdiction. ${ }^{101}$ In the context of personal jurisdiction, on the other hand, the reason for asking the question is presuinably to assess the degree of inconvenience inposed upon the defendant by compelling it to litigate a claim in the forum that is unrelated to its activities there. Having focused the question this way, however, it is still not clear which of the possible definitions of substantiality may best capture that concern. ${ }^{102}$

discrediting the "consent" theory on the ground that those cases involved lack of minimum contacts, which were "indisputably" present in this case. Id. at 106-07. A closer examination of the facts reveals, however, that what was indisputable was that the defendant had acted purposefully in the forum, not that jurisdiction was proper there on a claim unrelated to that activity. The court further justified jurisdiction by stating that its assertion furthered the state's avowed policy of treating authorized foreign corporations and domestic corporations equivalently. Id. at 107. That policy, however, does not justify the imposition of this burden on noncitizen corporations since the actual benefit to the defendant, as well as its responsibility to the sovereign, is not equivalent to that of citizens. See also Silversmith v. Kenosha Auto Transp., 301 N.W.2d 725 (Iowa 1981), where the court uncritically assumed that statutes subjecting corporations to jurisdiction in any forum in which they are licensed to or are doing business face no constitutional challenge. Indeed, the court described forum non conveniens as "a necessary response to the expanding bases of personal jurisdiction derived from long-arm statutes, ... which have incrcased the likelihood that a court will be faced with an imported lawsuit having little or no connection with the state in which the action was brought." Id. at 726 (citations omitted). Of course, to the extent such statutes grant jurisdiction over claims that arise out of the in-state activities enumerated therein, no such use of forum non conveniens is necessary.

101. Kelly v. United Steel Corp., 284 F.2d 850 (3d. Cir. 1960), discussed in 13B C. WRIGHT, A. Miller \& E. Cooper, Federal Practice and Procedure $\$ 3625$.

102. Only one circuit has set out relatively clear guidelines as to the extent of activity necessary to support jurisdiction. It did so in the context of determining jurisdiction over a corporation based upon activities of its subsidiary in the forum that were unrelated to the plaintiff's claim. See, Volkswagenwerk Aktiengesellschaft v. Beech Aircraft Corp., 751 F.2d 117 (2d Cir. 1984); see also Transure, Inc. v. Marsh and McLennan, Inc., 766 F.2d 1297, 1299 (9th Cir. 1985) (refusing to assert 
The definitional difficulty reflects the difficulty in the underlying assumption that if a defendant's continuous activity is "substantial," the burden imposed upon him by litigating in the forum is less than if his contmuous activity there is not "substantial." It is not obvious why this should be so. Simply because some portion of a defendant's business or other activities occur in the forum, it does not follow that the forum is necessarily convenient for the litigation of a claim that arose elsewhere. Citizenship may obviate the need for convenience; substantiality ought not to do so. Furthermore, the systemic interest of the forum is much less, if it exists at all, where the defendant is not a citizen. If the plaintiff is a citizen, this does create some interest in providing him with a forum convenient to him, but such an interest, standing alone, does little to justify the imposition of a burden upon the defendant.

Rather than rely upon some yardstick to measure "substantiality," the degree of inconvemience imposed upon the noncitizen defendant should be considered directly to determine whether the resulting burden is violative of due process. In general, it will be. If it is not, neither the "public" nor the "private" factors of forum non conveniens should justify dismissal of the suit. ${ }^{103}$ Three representative fact patterus demonstrate these conclusions.

The facts of Gulf Oil Corp. v. Gilbert ${ }^{104}$ are anything but unique and constitute perhaps the easiest example of a case dismissed on the grounds of forum non conveniens that should have been dismissed for lack of personal jurisdiction. As noted above, ${ }^{105}$ the defendant was engaged in contimuous activity in the New York forum, but the nonresident plaintiff's claim arose wholly out of activities im Virginia. Clearly, in current jurisdictional terminology, Gulf Oil had "purposefully avail[ed] itself of the privilege of conducting activities in the forum, thus invoking the ben-

jurisdiction over a parent corporation with insufficient independent state contacts, when its separation from its local subsidiary, though formal, was real; citing Cannon Mfg. Co. v. Cudahy Packing Co., 267 U.S. 333, 337 (1925)); cf. Top Form Mills Inc. v. Sociedad Nationale Industria Applicazione Viscosa, 428 F. Supp. 1237 (S.D.N.Y. 1977).

103. The traditional, contrary, position is perhaps most clearly expressed in Time, Inc. $v$. Manning, 366 F.2d 690 (5th Cir. 1966), in which the court places jurisdiction and venue on a continuum, permitting a forum to be able "fairly" to assert jurisdiction while at the same time dismissing the claim on the grounds of forum non conveniens or transferring it pursuant to 28 U.S.C. $\$ 1404$ (a) because of "inconvenience." Manning, 366 F.2d at 698. The court fails to articulate how to distinguish "fairness" in a constitutional sense from "inconvenience" in a common law sense. Although recognizing that "[b]oth [jurisdiction and venue] are designed to test the fairness to the defendant and the degree of inconvenience caused him by requiring him to litigate in a particular court," the court provided no guidance with respect to how the concepts differ. "Fairness" and "inconvenience" are indeed two different words, but when each in both contexts concerns contacts between the defendant, the litigation and the forum, their meaning is not obviously different.

104. 330 U.S. 501 (1947).

105. See supra note 50 and accompanying text. 
efits and protections of its laws."106 Just as clearly, however, the burden imposed upon the corporation would be great if the litigation were to proceed in New York. Furthermore, to the extent that competing state interests are relevant to a jurisdictional analysis, Virginia's interest was great and New York's nonexistent.

Recognizing these facts, the Supreme Court dismissed the claim, but for the wrong reason. Gulf Oil was not a citizen of New York, nor was New York the only forum available to the plaintiff. The jurisdictional focus, therefore, should have been upon the protection afforded by the due process clause agamst inconvement hitigation. The burden imposed upon the defendant by an assertion of jurisdiction by the New York district court differed in nature and extent from the burden it had voluntarily assumed by acting in the forum. ${ }^{107}$ The claim should have been dismissed for lack of personal jurisdiction. ${ }^{108}$

106. Hanson v. Denckla, 357 U.S. 235, 253 (1958).

107. This comparison of burdens-of the burden imposed upon the defendant by litigating the unrelated claim in the forum and of the burden that litigating a claim arising out of the defendant's activity in the forum would impose-was introduced by the California Supreme Court in Buckeye Boiler Co. v. Superior Court, 71 Cal. 2d 893, 458 P.2d 57, 80 Cal. Rptr. 113 (1969). There, the court noted that any litigation imposes some burden on the defendant, but that jurisdiction would be improper when the defendant could demonstrate that the burden imposed on it by forcing it to appear in a suit unrelated to its activity in the state was different in nature and extent from the burden of defending a hypothetical suit arising from its forum activities. Id. at 58.

Although the court's approach does not emphasize International Shoe's concern with substantiality and arguably errs by placing the burden on the defendant to demonstrate inconvenience (analogous to forum non conveniens practice), it is eminently logical.

108. See also Koster v. Lumberman's Mut. Casualty Co., 330 U.S. 518 (1947) (a stockholder's derivative claim against an Illinois corporation and its president and a second Illinois corporation for breach of fiduciary duty and an accounting brought in the Eastern District of New York; plaintiff purchased his stock in New York, and the corporations did business in the state; there was no personal jurisdiction dispute, although all actions that formed the basis of the plaintiff's claim had occurred in Illinois); Sibaja v. Dow Chem. Co., 757 F.2d 1215, 1216 n.2 (11th Cir. 1985) (defendant was qualified to transact business in the forum; as a inajor international corporation, it was subject to jurisdiction in the courts of every state and of several foreign countries-a realization that should have focused attention on the need to restrict such jurisdiction primarily to suits that arose out of forum activities); Overseas Nat'l Airways Inc. v. Cargolux Airlines Int'l., S.A., 712 F.2d 11 (2d Cir. 1983) (opinion does not reveal any basis for assertion of jurisdiction over the Luxembourg defendant). In Pain v. United Technologies Corp., 637 F.2d 775 (D.C. Cir. 1980), cert. denied, 454 U.S. 1128 (1981) the defendant designed and manufactured a helicopter in Connecticut that crashed in the North Sea while owned and operated by a Norwegian corporation. Plaintiff brought suit in the D.C. Circuit, which was dismissed on grounds of forum non conveniens in favor of Norway. Note that if the plaintiff had sued in the District Court of Connecticut, jurisdiction would have been proper and the disunissal ought to have been denied. See supra notes 28-39 and accompanying text. Apparently, no one argued to the court that a transfer to Connecticut pursuant to 28 U.S.C. $\$ \S 1404(a)$ or 1406 would have been a preferable choice. Compare Macedo v. The Boeing Co., 693 F.2d 683 (7th Cir. 1982) (on facts closely parallel to those of Pain, the circuit court reversed the district court's foram non conveniens dismissal and remanded for further consideration of factors relevant to whether the suit should be transferred to Washington, where the aircraft had been manufactured).

See also, Farmanfarmaian v. Gulf Oil Corp., 588 F.2d 880 (2d Cir. 1978) (defendants presumably did continuous business in New York, but were sued for an alleged breach of an 
Occasionally, although the initial statement of facts may parallel Gulf Oil, further consideration reveals that the chosen forum is not particularly inconvenient-jurisdiction is proper and dismissal on the grounds of forum non conveniens is not. For example, in Hague $v$. Allstate Insurance Co., ${ }^{109}$ the plaintiff, in her home state of Minnesota, sued the nonresident corporate defendant on a claim arising out of the death of her husband in a Wisconsin automobile accident. There was no dispute that Allstate was conductimg continuous activity in the forum, nor was there any dispute that the claim did not arise from that activity. The accident occurred elsewhere, and the policy which formed the basis of the widow's suit was issued in Wisconsin, where the couple had lived at the time of the husband's death. In other words, only the relocation of the plaintiff to the forum, after her claim arose, distinguished this fact pattern from Gulf Oil.

Needless to say, the assertion of jurisdiction was not challenged, but the Supreme Court affirmed Minnesota's refusal to dismiss the suit on the grounds of forum non convemiens. The claim was for a declaratory judgment and raised issues of insurance policy interpretation which required no witnesses. The Court pointed out that the Wisconsin hus-

agreement reached in Iran between Iranian parties, including an Iranian $40 \%$ subsidiary of the defendants); Mizokami Bros. v. Baychem Corp., 556 F.2d 975 (9th Cir. 1977) (suit in Arizona district court for damages allegedly arising from contamination of a shipment of peppers from Mexico by excessive residue of a chemical manufactured by Baychem in Missouri; although the court did dismiss plaintiff's claims against Baychem's German parent corporation, for whom the chemical was manufactured, and its Mexican subsidiary, to whom it was sold and who, in turn, sold it to the Mexican pepper farmers, jurisdiction over Baychem itself was upheld because of the unrelated business which it conducted in Arizona; the claim against Baychem was dismissed on grounds of forum non conveniens), cert. denied, 434 U.S. 1035 (1978); Koupetoris v. Konkar Intrepid Corp., 535 F.2d 1392 (2d Cir. 1976); Garis v. Compania Maritima San Basilio, S.A., 386 F.2d 155 (2d Cir. 1967) (personal jurisdiction conceded on the basis of service in New York on a New York corporation which was the defendant's limited agent, although the seaman's claim for injury on the high seas had no conceivable relation to the agency); Ionescu v. E.F. Hutton \& Co. (France) S.A., 465 F. Supp. 139 (S.D.N.Y. 1979) (suit against French corporation dismissed on grounds of forum non conveniens; personal jnrisdiction based upon its parent's position as a wholly owned subsidiary of a Delaware corporation doing business in New York); Del Monte Corp. v. Everett S.S. Corp., 402 F. Supp. 237, 243 (N.D. Cal. 1973) (The court at least questioned the sufficiency of unrelated acts by defendant's agent in California and recognized that faetors which it considered determinative of the forum non conveniens dismissal also mitigate against the court's assertion of personal jurisdiction. Nonetheless, the deeision rests upon the common law rather than the constitutional issue); Wieser v. Missouri Pacific R.R., 456 N.E.2d 98 (Ill. 1983) (FELA suit in Illinois on a claim arising out of an accident in Oklahoma); Anderson v. Great Lakes Dredge \& Dock Co., 309 N.W.2d 539 (Mich. 1981) (maritime suit on a cause of action that arose in Florida dismissed on the grounds of forum non conveniens; no personal jurisdiction argument was made but the court noted that the defendant's unrelated forum business would sustain such jurisdiction). $C f$. Wheeler v. Societe Nationale des Chemins de Fer Francais, 108 F. Supp. 652 (S.D.N.Y. 1952) (Florida plaintiff's claim arising out of French railroad accident not dismissed on grounds of forum non conveniens when defendant engaged in continuous though unrelated activity in the forum, and eyewitnesses to the accident were currently in the United States).

109. 449 U.S. 302 (1980), reh'g denied, 450 U.S. 971 (1981). 
band had had contact with Minnesota; he had worked in the state and had lived and died close to the border. Additionally, the Minnesota courts were the source of the wife's appointment as personal representative of the deceased, in which capacity she instituted her suit; the Wisconsin courts had not appointed any such representative. The defendant relied only on the difference in substantive law to be applied. The court held that if Minnesota was constitutionally permitted to use its own law, that difference was insufficient to support a forum non conveniens dismissal.

If the Court in Hague had focused on personal jurisdiction rather than on forum non conveniens, the result would have been the same. The only "inconvenience" to which the defendant could point was the change $\mathrm{m}$ applicable law, and that is not the kind of factor that alone makes a forum unfair or unreasonable for purposes of personal jurisdiction. Given Allstate's continuous activity in Minnesota, it was no more difficult to defend there than it would have been in Wisconsin-or, for that matter, in any state in which the firm acted continuously.

Two points need to be noted, however. First, the close physical proximity of Minnesota and the Wisconsin site, the deceased's employment in Minnesota, and the plaintiff's current presence there are all irrelevant to the burden imposed upon the defendant. The deceased's employment, at least, seenis equally irrelevant to the balancing of conveniences required by Gulf Oil's "private" factors. The determinative consideration is the nature of the required proof, which could have been presented just as easily in Minnesota as in Wisconsin.

Second, once the defendant's activity has been properly characterized as contimuous, rather than single and isolated, the jurisdictional analysis is not dependent upon a finding of "substantiality." In this type of case, the defendant's continous, purposeful availment of the forum is sufficient to support the assertion of jurisdiction because the choice of forum does not significantly affect the burden of defense. Few cases, however, fit the Hague pattern.

The facts of World-Wide Volkswagen Corp. v. Woodson ${ }^{110}$ present the third and most common scenario. Plaintiffs, who had purchased their vehicle in New York and were injured in a car accident in Oklahoma, brought suit in Oklahoma against the nianufacturer of the vehicle and those in the chain of its distribution and sale.

The actual issue in the case was the propriety of jurisdiction over the regional distributor and retail dealer, neither of whom acted in the forum. The importer defendant did not appeal a demal of its motion to dismiss for lack of jurisdiction, and the manufacturer never challenged

110. 444 U.S. 286 (1980). 
jurisdiction. Both of those defendants were presumably engaged in continuous activity in Oklahoma, but the claims against them did not arise out of, nor were they in any sense related to, that activity. Cars of the same kind as the one imvolved in the accident were imported to the forum, but their presence there was totally irrelevant to plaintiffs' claims. Therefore, jurisdiction should not have been presumed to be proper. Instead, if requested to do so, the court should have considered the burden upon the defendants that an assertion of jurisdiction would impose.

Unlike the claim in Hague, the claims in World-Wide were not tried as easily, from the defendants' point of view, in any forum. Allegations of defective design and manufacture inevitably call for witnesses and documentation most probably located at the manufacturing site in Germany. The activities there "gave rise" to the cause of action, and jurisdiction there over the manufacturer would have been unquestionable.

Nevertheless, the manufacturer did act purposefully in the United States, soliciting customers and selling and servicing its products pursuant to various contracts with corporations in the United States. Such activity has long been thought to be sufficiently "related" to sustain jurisdiction where, for example, the defective vehicle was purchased-here, in New York. One way, therefore, of justifying Oklahoma's jurisdiction would be to demonstrate that the manufacturer's burden there is no greater than it would have been in New York. In both instances, evidence concerning the defendant's activities would be located elsewhere and would have to be translated. Although Oklahoma is physically further from Germany than is New York, current modes of transportation minimize whatever additional burden on the defendant the extra distance imposes. Indeed, because the injury occurred in Oklahoma and, therefore, evidence with respect to the issue of damages was there, Oklahoma might have been more convenient for the defendant than was New York. Jurisdiction in Oklahoma would thus be proper, and dismissal on grounds of forum non converiens would not.

Again, however, both these conclusions are based upon an analysis of the practical burdens imposed by hitigating in the chosen, rather than an alternative, forum - an analysis required when jurisdiction is premised on activities of the defendant unrelated to the plaintiff's claim.

If a noncitizen defendant, then, engages in continuous activities in the forum, unrelated to the claim brought against her there, personal jurisdiction is proper if the burden imposed upon her is no different than either the one she accepted by acting there ${ }^{111}$ or the one that could constitutionally be imposed upon her by the forum in which the cause of action arose. The equivalency of those burdens would, as well, defeat

111. See supra note 107. 
any argument that an alternative forum was so much more convenient that the suit should be dismissed under the doctrine of forum non conveniens. When such equivalency is absent, however, as in Gilbert, dismissal should be premised on a lack of personal jurisdiction.

Even if "substantiality" is not viewed as reflecting an assumption about convemience and burden, International Shoe directs the courts' attention to the relationship between the defendant's contacts with the forum, substantial or otherwise, and the fair and orderly administration of the laws. ${ }^{12}$ Both the public and private factors of Gilbert must be taken into account to determine whether the location of the litigation in the plaintiff's chosen forum will promote or hinder such adinininstration. ${ }^{113}$

To the extent that courts assume that continuous activity in the forum sustains jurisdiction on an unrelated claim, they fail to consider the "fair and orderly administration of the laws," just as they fail to consider the "substantiality" of the defendant's conduct. A good example of appropriate use of defendant/forum/litigation contacts in this context is Insurance Co. of North America v. Marina Salina Cruz. ${ }^{114}$ Non-Alaskan plaintiffs, the owner and insurer of a vessel that sank in Alaskan waters, sued a Mexican shipyard in the Alaskan district court, alleging that the shipyard's neghigent acts in Mexico caused the vessel to sink. The circuit court held that in order for personal jurisdiction to be proper, the defendant must have purposefully availed itself of the privilege of conducting activity in the forum related to the cause of action and that the assertion of jurisdiction must be "reasonable." Presumably, on these facts, there was no action by the defendant sufficient to sustain a finding of purposeful availinent. Although the slipyard was aware that the vessel it serviced was bound for Alaska, it had not solicited business in the state, had not utilized any stream of commerce that included the state, and had not itself targeted Alaska as the destination of its services or products. ${ }^{115}$

The dismissal of the plamtiffs' suit was based upon a finding that, even assuming the existence of purposeful availment, the assertion of jurisdiction would be unreasonable. Seven factors were identified as relevant to the reasonableness inquiry, each of which is relevant to the fair and orderly administration of the laws as well as to a classic forum non conveniens analysis. Considerations such as the practical burden on the defendant of responding in Alaska, the location of evidence, the need to

112. 326 U.S. at 316.

113. See, e.g. Fisher Governor Co. v. Superior Court, 53 Cal. 2d 222, 347 P.2d 1, 1 Cal. Rptr. 1, (1959).

114. 649 F.2d 1266 (9th Cir. 1981)

115. Cf. Calder v. Jones, 465 U.S. 783 (1984); McGee v. International Life Ins. Co., 355 U.S. 220 (1957); Gray v. American Radiator \& Standard Sanitary Corp., 22 Ill. 2d 432, 176 N.E.2d 761 (1961) (discussed in World-Wide Volkswagen Corp. v. Woodson, 444 U.S. 286 (1980)). 
use Mexican law, the enforceability of the judgment and thus the ability of the court to grant convenient and effective relief, all indicated that the litigation would be more reasonably situated in Mexico, an available alternative forum.

The court also discussed the relative interests of Alaska and Mexico, recognizing a serious potential affront to the sovereignty of the latter if the suit against the shipyard, which belonged to a Mexican governmental agency, proceeded in Alaska. The court had noted initially that the extent of the defendant's purposeful interjection into the forum, even if sufficient to find purposeful availment, was minimal.

The analytical structure of the opinion is troublesome, although the court's approach is far preferable to relegating these "reasonableness" factors to the haze of forum non conveniens. Had the defendant in fact purposefully availed itself of the privilege of conducting activities in Alaska related to the cause of action, jurisdiction ought to have been sustained. Certaim of the seven factors would have changed, most apparently the concern with an affront to Mexican sovereignty and the degree of recognizable burden iniposed upon the defendant. The existence of purposeful acts related to the claim also supports a conclusion that jurisdiction is reasonable. The conceptual justification for deinanding purposeful availment is that its existence justifies the concomitant burden of defending in the forum a clain related to the purposeful activity, even if a defendant has acted similarly elsewhere and litigation there would in some way be more convenient. ${ }^{116}$ To the extent the opinion suggests otherwise, it fails to take into account the theoretical result of its "finding" of purposeful availnent.

This congruence between "purposeful availing" and what is more ordinarily referred to as "the fair and orderly administration of the laws" is dependent, however, upon the requirement that the acts that constitute purposeful avaiting be related to the claim brought against the defendant. When jurisdiction over a noncitizen defendant is based upon the defendant's continuous, purposeful, but unrelated activities in the forun, the "reasonableness" factors that the Ninth Circuit enıphasized ought to defeat jurisdiction at the outset, thus avoiding any need to rely upon forun non conveniens. ${ }^{117}$

To consider the Gilbert factors twice is absurd. To fail to consider then in a jurisdictional analysis is wrong, and, therefore, to consider then under the rubric of forun non conveniens is unnecessary.

116. See, e.g., Keeton v. Hustler Magazine, Inc., 465 U.S. 770 (1984).

117. For applications of the same conjunctive test, raising similar analytical problems although again reaching correct resuits, see Pacific Atl. Trading Co. v. The M/V Main Express, 758 F.2d 1325 (9th Cir. 1985); Paccar Int'1, Inc. v. Commercial Bank of Kuwait, S.A.K., 757 F.2d 1058 (9th Cir. 1985). 


\section{II \\ Prescriptive JURISDiction AND Forum NON CONVENIENS}

When a court is asked to determine whether its sovereign may properly regulate the conduct of parties that has given rise to a dispute within its subject matter jurisdiction, ${ }^{118}$ its focus once again is on contacts between the defendant, the litigation, the forum, and, perhaps, competing fora. Here however, the primary reason for the concern with contacts is not fairness to the defendant, which underlies a personal jurisdiction analysis, but the interests of the concerned fora. If the assertion of prescriptive jurisdiction is seen as reflecting the existence of cognizable forum interests only, ${ }^{119}$ the focus will be on the scope of the sovereign power of the forum. If the assertion of such jurisdiction reflects consideration of the comparative strength of foreign and forum interests, the court will also examine the interests of other fora in the dispute.

To the extent that the court's decision does take into account the interests of alternative fora as well as its own, the public factors of forum non conveniens are subsumed in its prescriptive jurisdictional analysis. ${ }^{120}$ To the extent that the court's decision focuses only on the contacts with the chosen forum, of course, only some of those public factors are taken into account. In the latter instance, it may be argned that forum non conveniens continues to have a role to play, albeit a drastically limited one, in providing a mechamsm for dismissal of litigation in which retention of the litigation would offend foreign sovereign interests. But if contacts with the forum properly sustam personal and prescriptive jurisdiction, the offense would have to be severe to justify dismissal. A

118. Frequently, a federal court that has determined on the facts before it that extraterritorial application of United States law is not warranted will dismiss the suit for lack of subject matter jurisdiction (in the absence of complete diversity or a maritime claim). Technically, such a dismissal should be for failure to state a claim upon which relief may be granted, pursuant to FED. R. CrV. P. 12(b)(6). The difficulty is not that federal courts lack jurisdiction to hear cases brought under, for example, the Jones Act. Rather, the problem is that the Jones Act itself does not proscribe the defendant's conduct and, therefore, does not offer the plaintiff any relief. Nicol v. Gulf Fleet Supply Vessels, Inc., 743 F.2d 289 (5th Cir. 1984); see also AVC Nederland B.V. v. Atrium Inv. Partnership, 740 F.2d 148 (2d Cir. 1984) (in which the court recognizes this distinction in the context of the Securities Exchange Act).

The problem is not of particular importance, however, since neither a dismissal under FED. $\mathbf{R}$. Crv. P. 12(b)(6) nor a dismissal for lack of subject matter jurisdiction is discretionary. On the other hand, a court may raise lack of subject matter jurisdiction on its own motion, and the issue may be raised for the first time on appeal; neither is true with respect to failure to state a claim upon which relief may be granted. As a practical matter, however, the issue of applicable law is inevitably raised at the trial level by the defendant.

119. This is the current approach with respect to constitutional limitations on a state's choice of law, when the competing body of law is that of another state. See infra Part II, Section $B$. Using this analysis, a forum is compelled to utilize a foreign body of law only because it lacks authority to utilize its own, and, therefore, resolution of the dispute mandates locating an alternative.

120. See supra note 3 . 
discretionary, common law doctrine would not appear to be an appropriate vehicle for its consideration. ${ }^{121}$

\section{A. Application of United States Law}

In the federal system, issues of prescriptive jurisdiction arise as issues concerning the proper extraterritorial scope of United States law. If the conduct giving rise to a cause of action occurred in the United States, the authority of the United States to attach legal consequences to that conduct is as clear as its authority to control the conduct of its nationals. ${ }^{122}$ But prescriptive jurisdiction also is frequently asserted over conduct which occurred outside the United States because of the effect such conduct had here. ${ }^{123}$ It is that basis of jurisdiction which has dramatically imcreased the number of situations in which more than one sovereign will have a legitimate argument that its law should govern the conduct in question. It is also that basis of jurisdiction which has prompted sonie courts to hold that, before United States law can properly be applied to a dispute, it is necessary to balance the interests of the United States against those of other niterested sovereigns to deternine which nation's interest is primary. This balancing-of-interests approach is best demonstrated in a number of cases dealing with the extraterritorial apphication of the antitrust laws.

Timberlane Lumber Co. v. Bank of America, N.T. \& S.A. ${ }^{124}$ originally set forth the need to refer to the interests of other nations in regulating conduct outside the United States which had had an effect in the United States. A California bank, its wholly owned subsidiary, and various individuals in Honduras allegedly had prevented the plaintiff from conpeting in Honduras for the milling and exporting to the United

121. Even such a truncated role for forum non conveniens is unnecessary as well as inappropriate. If a forum declines to consider the interests of other sovereigns in determining whether it may assert prescriptive jurisdiction, those interests may nonetheless be considered, usually under the rubric of comity, in determining whether to actually assert such jurisdiction. See Industrial Inv. Dev. Corp. v. Mitsui \& Co., 671 F.2d 876, 884 (5th Cir. 1982). This, of course, raises the same problems that the use of forum non conveniens would raise. See Gerber, Beyond Balancing: International Law Restraints on the Reach of National Laws, 10 YALE J. INT'L L. 185, 186-89, 205-06, 217-20 (1985); Lowe, The Problems of Extraterritorial Jurisdiction: Economic Sovereignty and the Search for a Solution, 34 INT'L \& CoMP. L.Q. 724, 728-33 (1985). For a contrary assertion, see Note, Reasonableness as a Limit to Extraterritorial Jurisdiction, 62 WASH. U.L.Q. 681 (1985).

122. RESTATEMENT (SECOND) OF FOREIGN RELATIONS LAW OF THE UNITED STATES $\$$ 17, 30 (1965); see, e.g., Wallace, Extraterritorial Jurisdiction, 15 LAW \& PoL'Y INT'L Bus. 1099 (1983). Of course, the power to do so need not be exercised. For example, the American citizenship of a defendant is not sufficient, by itself, to justify application of the United States securities laws. See IIT v. Vencap, Ltd., 519 F.2d 1001, 1016 (2d Cir. 1975); Hacker \& Rotunda, The Extraterritorial Regulation of Foreign Business Under the U.S. Securities Laws, 59 N.C.L. REv. 643, 646 (1981).

123. The first clear statement of this basis of prescriptive jurisdiction is found in United States v. Aluminium Co. of Am., 148 F.2d 416, 443 (2d Cir. 1945).

124. 549 F.2d 597 (9th Cir. 1976). 
States of Honduran lumber, in order to retain control of those operations in individuals financed and controlled by the bank. These activities, according to the plaintiff, had had a direct and substantial effect on the foreign coinınerce of the United States, thus justifying their regulation pursuant to the Sherman Act ${ }^{125}$ and the Wilson Tariff Act. ${ }^{126}$

The Nimth Circuit, rejecting the traditional requirement of a "substantial" or an "intentional" effect in the United States as a sufficient restraint on this jurisdictional basis, held that

A tripartite analysis seems to be indicated .... [T] require in the first instance that there be some effect-actual or intended - on American foreign commerce before the federal courts may legitimately exercise subject matter jurisdiction under those statutes. Second, a greater showing of burden or restraint may be necessary to demonstrate that the effect is sufficiently large to present a cognizable injury to the plaintiffs and, therefore, a civil violation of the antitrust laws. Third, there is the additional question which is unique to the international setting of whether the interests of, and links to, the United States-including the magnitude of the effect on American foreign commerce-are sufficiently strong, vis-à-vis those of other nations, to justify an assertion of extraterritorial authority. ${ }^{127}$

The court continued:

The elements to be weighed include the degree of conflict with foreign law or policy, the nationality or allegiance of the parties and the locations or principal places of business of corporations, the extent to which enforcement by either state can be expected to achieve compliance, the relative significance of effects on the United States as compared with those elsewhere, the extent to which there is explicit purpose to harm or affect American commerce, the foreseeability of such effect, and the relative importance to the violations charged of conduct within the United States as compared with conduct abroad. A court evaluating these factors should identify the potential degree of conflict if American authority is asserted. A difference in law or policy is one likely sore spot, though one which unay not always be present. Nationality is another; though foreign governments may have some concern for the treatment of American citizens and businesses residing there, they primarily care about their own nationals. Having assessed the conflict, the court should then determine whether in the face of it the contacts and interests of the United States are sufficient to support the exercise of extraterritorial jurisdiction. ${ }^{128}$

Needless to say, the district court had not undertaken the required analy-

125. 15 U.S.C. $\$ \S 1-7$ (1982).

126. 15 U.S.C. $\S \S 8-9$ (1982).

127. Timberlane Lumber, 549 F.2d at 613 (footnotes omitted).

128. Id. at 614-15 (footnotes omitted). 
sis; the case was remanded. ${ }^{129}$

Timberlane is clearly correct in its realization that a finding of effect in the United States does not address in any way the competing interests of foreign sovereigns in regnlating the defendant's conduct. Yet, in any dispute not totally local, an assertion of regnlatory authority by one sovereign will always have an effect on the interests of other nations. Recognition of that linkage is at the heart of the act of state doctrine, ${ }^{130}$ and some courts, although rejecting its role in initially determining the existence of prescriptive jurisdiction, nevertheless consider it in determining the propriety of an assertion of-as opposed to the power to assertjurisdiction.

For exaniple, in Industrial Investment Development Corp. v. Mitsui $\& C o .,^{131}$ plaintiffs alleged a conspiracy to prevent them from harvesting trees in Indonesia and exporting lumber to the United States. In upholding the apphication of United States law to the defendant's activities, the court began by finding that the competition between the parties to obtain foreign sources of supply for export to the Umited States obviously affected United States foreign conimerce. It then went on to recognize that, if application of United States law to foreign conduct would violate principles of conity, conflicts of law, or international law, it ought not to be apphied. The court held that such a decision was one of law, fully reviewable on appeal, rather than one within the discretion of the trial judge.

At the same time, the court rejected Timberlane as a test for subject nuatter jurisdiction-that is, prescriptive jurisdiction-although why it

129. On remand, the district court dismissed the plaintiff's claims. 574 F. Supp. 1453 (N.D.Cal. 1983). The circuit court affirmed, 749 F.2d 1378 (9th Cir. 1984), and the Supreme Court has denied certiorari. 105 S. Ct. 3514 (1985). See infra note 137 for a discussion of the Ninth Circuit opinion.

Senator Dennis DeConcini (D. Ariz.) recently introduced the Foreign Trade Antitrust Improvement Act of 1985 (S. 397), which would, in effect, mandate use of the Timberlane approach in antitrust cases, as well as limiting recovery to actual damages if that would minimize adverse effects on foreign interests which had been adjudged insufficient to preclude entirely the application of United States law. Interestingly, much of the negative comment about the bill focuses on the concerns later cases have articulated about how to achieve the proposed balancing. 48 B.N.A. 1130 31 (62785); see infra notes $138-44$ and accompanying text for a suggested resolution of the perceived difficulties.

130. The doctrine ordinarily precludes judicial review of the legality of certain acts of other governments, in an attempt not to interfere with the executive's political conduct of foreign affairs. Banco Nacional de Cuba v. Sabbatino, 376 U.S. 398 (1964). Not surprisingly, parties opposing the extraterritorial application of United States law because of the interests of a foreign government may also argue that their activities were commanded by that government so as to preclude review of their legality. Also not surprisingly, the defense is a difficult one to prove. See, e.g., Mannington Mills, Inc. v. Congoleum Corp., 595 F.2d 1287 (3d Cir. 1979); see also In re Uranium Antitrust Litigation, 617 F.2d 1248, 1254 (7th Cir. 1980); Timberlane, 549 F.2d at 607 (emphasizing the need to consider why the foreign government had acted); Continental Ore Co. v. Union Carbide, 370 U.S. 690 (1962).

131. 671 F.2d 876 (5th Cir. 1982), vacated and remanded on grounds other than the extraterritorial analysis, 460 U.S. 1007 (1983). 
did so is obscure. The inquiry was said to be too "wide-ranging" to be used in determining the scope of jurisdiction intended by Congress. The issue inay be purely seniantical and is inoot on these facts, since no action by the Indonesian government constituted even approval of the defendant's acts and those acts inay in fact have also violated Indonesian laws and pohicy. ${ }^{132}$ But to relegate the interests of other states to an inquiry subsequent to the prescriptive jurisdictional one serves no particular purpose and niay be seen abroad as denigrating the importance of the interests of other sovereigns. ${ }^{133}$ These interests should be considered in the prescriptive jurisdiction inquiry itself.

The extraterritorial application of United States antitrust laws presents one of the niost difficult fact patterns in balancing conipeting sovereign interests. The United States law is designed to protect certain doinestic interests; the arguably applicable foreign law inay be designed precisely to prevent iniplenientation of the United States law in order to protect foreign interests threatened by its objectives. Monopolistic practices are not everywhere barred, nor does their legal status under other countries' laws necessarily reflect a failure to consider whether they ought to be barred. Such practices nuay be actively encouraged by a foreign government; if the effects of such practices are felt in the United States, clearly the purpose belind one nation's law will be thwarted. ${ }^{134}$

Laker Airways Ltd. v. Sabena, Belgian World Airlines ${ }^{135}$ challenges the usefulness of Timberlane's balancing approach. Many of the contacts listed there, the opinion asserts, are already evaluated in a traditional

132. See also In re Uranium Antitrust Litig., 617 F.2d 1248 (7th Cir. 1980); Mannington Mills, Inc. v. Congoleum Corp., 595 F.2d 1287 (3d Cir. 1979) (the majority refused to consider the Timberlane factors in the context of determining subject matter jurisdiction; a concurring opinion argued for their use there rather than as a rationale for abstention).

133. See supra note 121 .

134. See infra note 137 .

Recognition of a similar potential of conflicting regulatory purposes led, in part, to the Seventh Circuit's rejection of the extraterritorial application of the Age Discrimination in Employment Act of 1967, 29 U.S.C. $\$ \S 621-34$ (1982). Pfeiffer v. Wm. Wrigley Jr. Co., 755 F.2d 554 (7th Cir. 1985) (to preclude an employer from terminating an employee on the employee's 65 th birthday where the employee worked in Germany might subject the employer to liability in Germany, if that country mandated retirement at 65 in order to spread work and thus reduce unemployment); accord Zahourek v. Arthur Young \& Co., 750 F.2d 827, 828 (10th Cir. 1984); Thomas v. Brown \& Root, Inc, 745 F.2d 279, 281 (4th Cir. 1984); Cleary v. United States Lines, Inc., 728 F.2d 607, 610 (3d Cir. 1984). However, in 1984 Congress amended the Age Discrimination in Employment Act of 1967 to encompass claims brought by citizens working for companies or entities controlled by American employers. Congressional history indicates that the statute is not intended to apply if its application would place the employer in violation of the law of the host country, thus permitting continued consideration of the conflicts between sovereigns that motivated the Pfeiffer court. Older Americans Act Amendments of 1984, Pub. L. No. 98-549, 98 Stat. 1972; SENATE CoMm. ON LABOR and Human Resources, Older Americans ACT Amendments of 1984, S. Rep. No. 467, 98th Cong., 2d Sess. 28 (1984).

135. 731 F.2d 909 (D.C. Cir. 1984), noted in 17 LAW \& PoL'Y INT'L Bus. 157 (1985). 
prescriptive jurisdictional decision. These presumably include the nationalities, allegiances and principal places of business of the parties, the ability of the court to enforce its judgment, and the substantiality, foreseeabilty and intentional nature of United States effects. Other contacts such as the degree of conflict with foreign law, the ability of a foreign court to enforce its judgment, and the significance of foreign effects, are useful only im determining the existence of potential concurrent jurisdiction, and hence conflict, without indicating a resolution of that conflict. The "contacts which do purport to provide a basis for distingnishing between competing bases of jurisdiction, and which are thus crucial to the balancing process, generally imcorporate purely political factors which the court is neither qualified to evaluate comparatively nor capable of properly balancing."136 Examples of this last group of contacts or factors include the degree to which the desirability of the regnlation is generally accepted, the existence of justified expectations of the parties-justification implying an acceptance of the desirability of the law-and the importance of the regnlation to the regulating state.

Clearly, in order for the Timberlane approach to be effective, courts must be able to assign relative weights to the interests that they balance. ${ }^{137}$ Moreover, the Laker court is also clearly correct when it points out that the judiciary is ill-designed to cope with issues such as the importance to any government or the acceptance by any people of certain laws and legal goals. Whether it is more important to protect consumers from ineffective products sold at inflated prices-that is, to foster compe-

136. Laker Airways, 731 F.2d at 949.

137. When the Ninth Circuit confronted Timberlane for the second time, it was necessary to utilize the balancing test to determine jurisdiction, as the court affirmed the district court's findings of a cognizable effect on Umited States commerce caused by the defendants' foreign activities. 749 F.2d at 1383. The court's approach lends credence to some of the criticisms leveled at Timberlane $I$. Listing each of the seven factors identified in its first opinion, the court recited facts relevant to each and concluded in each instance that a particular factor weighed in favor of or against jurisdiction, slightly or significantly. Id. at 1384-86. The resulting opinion, in both its approach and substance, is disturbingly reminiscent of a multitude of forum non conveniens decisions that "weigh" the Gilbert factors in an identical fashion.

On the other hand, what appears to be the most persuasive factor in the eyes of the court is the degree of conflict with Honduran law and policy. Rather than preventing allocation of geographic or market territories by competitors, freedom of action is there guaranteed to promote economic efficiency. Thus, enforcement of United States law would lead to a "significant" conflict that "unless outweighed by other factors in the comity analysis, is itself a sufficient reason to deeline the exercise of jurisdiction over this dispute." Id. at 1384. In considering the relative signifieance of effects in the United States as compared with those elsewhere, the statistical data presented supports the court's conclusion that the defendants' activities related to a small portion of total United States lumber consumption, while they had a proportionately greater impact on Honduras's smaller market, as well as affecting jobs, foreign exchange, and taxes there. While the structure of the analysis is troublesome, the result is that which would be reached by use of the approach suggested in the text, and takes into consideration the factors that should be controlling. 
tition-than it is to protect emerging industries from ruinous competition is a choice for the legislature, not the courts.

But it is not necessary for the courts to gauge or measure such matters in order for them to determine when United States law should regulate conduct. Instead, it is possible to assume that the importance of each imterest $m$ the abstract is equivalent to the importance of its counterpart. The governmental interest in the regulation of specific conduct then becomes a function of the degree to which regulation by another sovereign will hamper the forum's regulatory purpose, or the degree to which regulation under the law of the forum will foster its purpose, in hight of the specific facts of the dispute. The determination of the weight accorded competing interests may remain difficult, but it is neither political nor impossible. ${ }^{138}$

Consider the use of such balancing in the fact pattern presented by Laker. The plaintiff, a British corporation, had alleged a conspiracy to prevent it from competing with assorted other airlines for transatlantic passengers, in violation of United States antitrust law. Certain of the

138. This approach is markedly similar to that utilized by states like New Jersey, whose choice of law rules direct the attention of the court to the governmental interests of the competing fora.

This approach requires a two-step analysis. The court determines first the governmental policies evidenced by the laws of each related jurisdiction and second the factual contacts between the parties and each related jurisdiction. A state is deemed interested only where application of its law to the facts in issue will foster that state's policy. This approach does not count up contacts and make quantitative determinations of interest based on which state has the greatest number of contacts. Instead, the qualitative nature of contacts is considered so that only contacts which are likely to promote valid state policies are considered relevant.

Henry v. Richardson-Merrell, Inc., 508 F.2d 28, 32 (3d Cir. 1975) (citation and footnote omitted). Utilization of the approach in the antitrust context is advocated in Note, The Use of Interest Analysis in the Extraterritorial Application of United States Antitrust Law, 16 CORNELL INT'L L.J. 147, 18087 (1983), which includes interesting examples of its use in various situations, and by William F. Baxter in U.S. Import Weekly (BNA), Oct. 17, 1981, at 31-32. Cf. Foster v. United States, 768 F.2d 1278, 1284 (11th Cir. 1985) (Illinois choice of law principles determine which state's wrongful death statute should be used to determine whether beneficiary need demonstrate dependence upon the deceased; utilizing the "most significant relationship" test, the court determined which affected state's policy would be most harmed by the use of another's law and which affected state's policy would be most clearly served by use of its own laws. The test is that used by the RESTATEMENT (SECOND) OF CONFLICT OF LAwS, $\S 145$.).

The approach also parallels one the Supreme Court has taken in the past in determining whether a state regulation violates the so-called "dormant" commerce clause. Without attempting to balance directly a state's interest, for example, in the safety of its citizens against the national interest in the free flow of commerce across state lines or the unimpeded access of foreign buyers and sellers to local markets, the Court has asked instead how effective the challenged state regulation is in achieving its announced purpose and to what extent implementation of that regulation will interrupt the flow of commerce or preclude access to the local markets. See, e.g., Southern Pac. Co. v. Arizona ex rel. Sullivan, 325 U.S. 761, 781-82 (1945). The analogy is not perfect, primarily because the Court has been more reluctant to interfere with some state goals than others and secondarily because, if the means chosen by the state are ineffectual, the Court may be skeptical about the announced purpose of challenged legislation. Neither bias would be appropriate in the context of prescriptive jurisdiction. 
defendants had then instituted a proceeding in Britain, against Laker, designed to prevent the district court from hearing Laker's claim. The district court issued a preliminary injunction against the remaining nonBritish defendants, restraining them from joining the British suit. The circuit court affirmed, finding that United States law properly regulated the defendants' activities because of the effects in the United States of their allegedly anticonipetitive conduct, which had taken place primarily abroad. The court also recognized that Britain had concurrent prescriptive jurisdiction, since the plaintiff and two defendants were British corporations and at least soine of the acts giving rise to the plaintiff's claim took place in Britain.

Although the court rejected Timberlane in the context of its discussion of how to choose between the two bodies of law, ${ }^{139}$ it did not totally ignore either the theoretical or practical interests of other sovereigns. The court noted that "if the anticonupetitive aspect of the alleged injury is not appreciable; the contacts with the United States are attenuated; and the actions of foreign governments denote the existence of strong foreign interests, then comity may suggest a lack of Congressional intent to regulate the alleged activity." 140

The first factor noted by the court is relevant because it speaks to the degree of United States interest in the regulation of conduct under United States law on these facts. The issue is not how important competition is; rather it is the extent to which the activities of the defendants harmed the interests protected by United States law. The court had earlier noted that the greatest impact of the alleged predatory pricing conspiracy was felt by United States passengers, who provided the largest percentage of all transatlantic fares. Thus, the interests of a large number of United States consumers, as well as a large percentage of consumers in the relevant market, would be severely harmed if that law were not used to regulate the defendants' conduct. The protection of those consuniers is at the heart of United States antitrust law. Furthermore, the court pointed out, the principal creditors of Laker, which was in liquidation, were United States citizens, and the injury they would suffer, should United States law (complete with treble damage provisions) not apply, was even more direct than the injury to United States consumers. ${ }^{141}$

139. Ordinarily, such a choice of law decision is not necessary in light of a finding of United States prescriptive jurisdiction. See supra note 7; see also infra note 205. If prescriptive jurisdiction is proper, the more usual approach to avoid application of the forum's law is to appeal to forum non conveniens. See Piper Aircraft Co. v. Reyno, 454 U.S. 235, 250 (1981). For a discussion of Piper, see supra notes 28-39 and accompanying text.

140. Laker Airways, Ltd. v. Salena, Belgian World Airlines, 731 F.2d 909, 938 (D.C. Cir. 1984) (footnotes omitted).

141. It may be argued that the antitrust laws were not designed to avoid the potential difficulties 
The second factor, the "contacts" with the United States or lack thereof, is properly considered in the first step of the prescriptive jurisdictional analysis: the determination of whether, aside from competing interests of foreign sovereigns, United States jurisdiction is appropriate because of the contacts between the parties, the claim and the forum. Absent such contacts, the United States court ought not to assert prescriptive jurisdiction and the suggested balancing is unnecessary. ${ }^{142}$

The third factor raised by the court's analysis of the demands of conity, the degree of foreign interest as indicated by the actions of foreign governments, is both puzzling and reminiscent of Timberlane, which the court specifically rejected. In the first place, it is hard to imagine how the British government could have inore forcefully indicated its objections to Laker's claim under United States law, and yet its objections did not preclude use of that law to regulate conduct and determine liability. In the second place, to permit a jurisdictional decision to rest, even in part, upon the actions of a foreign government appears unwise for at least two reasons: first, it places upon that government the burden of tracking all United States hitigation in which its interests are imphcated and of informing the United States courts of its response; and second, it leaves the decision of the degree of that interest to an obviously interested pohitical entity, ${ }^{143}$ with no assurance that the expressed degree of interest will bear any relationship to the actual degree of harm to articulated pohcies should foreign law not be used.

The court noted later in its opinion that it did "not see how a suit by a British corporation against Dutch and Belgian corporations involving anticompetitive activities allegedly taken by the defendants to protect their United States-Dutch and United States-Belgian air nrarkets

of Laker's creditors. Fostering competition, and thereby providing consumers with a choice of products and, presumably, reasonable prices, would not seem to parallel the interests that underlie the bankruptcy laws. True, as a practical matter the creditors will benefit if Laker's suit is successful, since its estate, against which their claims will be paid, will be enlarged. Furthermore, if Laker had been forced into liquidation because of the defendants' anticompetitive activities, its creditors were indirect victims of those activities. Nonetheless, the specific interests protected by the antitrust laws were not implicated by the position of the creditors.

142. Such contacts, of course, also are relevant to the existence of personal jurisdiction over the defendants, which was apparently not challenged in Laker. The Laker court's discussion of contacts emphasized the interest of the United States (although not of the District of Columbia) in regulating the conduct of businesses in the United States, reflected by the foreign airline's request for landing rights. Acceptance of those rights, the court states, constitutes submission to personal jurisdiction and operates to effectuate a policy of placing foreign corporations on an equal footing with domestic ones. Laker, 731 F.2d at 924-25; see supra Part I, Section B(2).

143. The United States court, of course, is also in some senses "interested" in the jurisdictional outcome. It is not implausible to assume that a United States court, confronted with a degree of demonstrable harm to United States interests if United States law was not applied, would be reluctant to refuse relief because of foreign interests. Nonetheless, the court is at least apolitical and competent to articulate and apply objective standards. 
adversely implicates British trading interests," ${ }^{144}$ which, the court agreed, would have been damaged if a British corporation had to pay the judgment. Although unfortunately conclusory, this seems to ask the right question: having first defined the British interest that allegedly will be harmed if United States law is applied, to what extent will use of that law on these facts cause the feared harm? If a British corporation is claiming, against non-British defendants, a benefit which Britain would not grant, does conferring that benefit injure the policy underlying its refusal by Britain? The Laker court obviously thought it would not. If that assessment is accurate, its jurisdictional decision was correctUnited States interests would be harmed unless the United States asserted prescriptive jurisdiction, and British interests were not harmed by such an assertion.

If the court's understanding of British imterests was inaccurate, the court needed to compare the degree of harm to each conpeting interest and regulate the defendants' conduct under the law which would do the least harm to coinpeting sovereign concerns. ${ }^{145}$ In either event, the systemic concerns expressed by the doctrine of forum non conveniens-the avoidance of burdening an uninterested forun with the resolution of a dispute which does not inplicate any of its policies, as well as the recognition of an alternative forum's interest when its policies are affected by the dispute-are reflected in the prescriptive jurisdiction decision.

The issue of extraterritorial application of United States law arises ni contexts other than antitrust of course. ${ }^{146}$ Numerous cases involve the scope of prescriptive jurisdiction under the securities laws. The increasing internationalization of the world's securities inarkets increases the nuinber of instances in which the jurisdictional issue will present the potential for conflict. ${ }^{147}$ Here, too, courts may look to effects within the United States to justify the application of United States law to conduct that occurs outside the United States. And here, too, the finding of such

144. Laker, 731 F.2d at 932-33.

145. For an alternative approach to the dilemma of the political balancing apparently required by Timberlane, see Gerber, supra note 121 .

146. There are numerous articles dealing with the issue of prescriptive jurisdiction in the antitrust context. See, e.g., Grippando, Declining to Exercise Extraterritorial Antitrust Jurisdiction on Grounds of International Comity: An Illegitimate Extension of the Judicial Abstention Doctrine, 23 VA. J. INT'L L. 395 (1983); Note, The Inconvenient Forum and International Comity in Private Antitrust Actions, 52 FORDHAM L. REV. 399 (1983); and a symposium on the issue and its corollaries published in 18 STAN. J. INT'L L. 241 (1982).

147. A rccent Securities and Exchange Commission request for comments on internationalization, while directed primarily at issues raised by the mechanics of trading, requested comments as well on the application of United States law to the multinational distribution of securities. See Exchange Act Release No. 21,958 [1984-1985 Transfer Binder] Fed. Sec. L. Rep. (CCH) 83,759 (Apr. 18, 1985). 
effects does not reflect any consideration of the interests of foreign sovereigns in regulating the defendant's activities.

Apparently, however, no court has adopted any variation of the Timberlane approach in the context of securities regulation. While theoretically troublesoine, this failure may not raise difficulties similar to those created by an absence of balancing in antitrust claims. No sovereign would seem to have a justifiable interest in protecting the kind of fraudulent conduct condemned by United States securities laws. ${ }^{148}$ Competing law nay differ in its focus, its emphasis, and its remedy; it may reach more or less activity than that regulated by the United States. But no country appears to sanction, for exainple, material inisrepresentations of fact in connection with the purchase and sale of securities. ${ }^{149}$ Consequently, the attachment by the United States of penalties to such conduct may not offend any foreign sovereign interests. The only obvious source of resentment, the subjection of its national to foreign law and foreign courts, is resolved by the need for contacts between that national and the forum in order to assert both prescriptive and personal jurisdiction. Two representative cases deinonstrate the likelihood that the Timberlane concerns need not be formally addressed in this context.

Grunenthal GmbH v. Hotz ${ }^{150}$ upheld the application of United States securities laws to a domestic transaction in foreign securities between foreign corporations and citizens, although the transaction had no effect in the United States. The court gave no consideration to the possible claims of foreign governments who obviously inight have been interested in the use of their own law. The basis of prescriptive jurisdiction, as well as personal jurisdiction, was the allegedly materially fraudulent conduct by the defendants in the forum and their use of the instrumentalities of interstate commerce to effectuate the fraud. ${ }^{151}$ Such

148. See infra note 153 .

149. For example, see $\S 10(b)$ of the Securities Exchange Act of 1934, 15 U.S.C. $\S 78(\mathrm{j})(\mathrm{b})$ (1982), and Rule 10b-5, 17 C.F.R. $\S 240$. 10b-5 (1985), promulgated thereunder.

150. 712 F.2d 421 (9th Cir. 1983).

151. Id. at 426. Forum activities must be material, that is, directly cause the loss, rather than merely preparatory to it, and must be significant with respect to the alleged violation. In Hotz, one defendant claimed control over the corporation whose stock was to be sold to the plaintiff for the first time in the United States. The contract for the sale of that stock was executed in the United States.

Hotz adopted the jurisdictional test set out in Continental Grain, Ltd. v. Pacific Oilseeds, Inc., 592 F.2d 409 (8th Cir. 1979). There, the plaintiff, an Australian subsidiary of a Delaware corporation, purchased all the stock of another Australian corporation from the defendants, Australian and California corporations and a California individual. The defendants allegedly failed to inform the plaintiff that certain stocks of seed of the purchased corporation were to be repossessed; the court found that the scheme of nondisclosure, conceived in and directed from the United States through the use of the mail and other instrumentalities of interstate commerce, was sufficient to sustain both the forum's prescriptive and personal jurisdiction. See also AVC Nederland B.V. v. Atrium Inv. Partnership, 740 F.2d 148, 153 (2d Cir. 1984); Straub v. Vaisman \& Co., 540 F.2d 591, 595 (3d Cir. 1976); IIT v. Vencap, Ltd., 519 F.2d 1001, 1017-18 (2d Cir. 1975); Travis v. 
conduct, if not regulated by United States law, would encourage foreign use of the forum by those who wished to act fraudulently, in clear contradiction to the goal of United States law to achieve a high standard of ethics in the securities industry. ${ }^{152}$ Even if it is assumed that other sovereigns do not share that goal and that the activities of the defendants would have been legal if undertaken at home, there is no dispute that actions here are subject to Umited States law. Furthermore, as noted above, the lack of a shared goal does not imply the existence of an opposing goal; no cognizable foreign interests were harmed by United States regulation of the activity under its own law. ${ }^{153}$

If the basis of prescriptive jurisdiction is the presence of effects in the United States, the facts more closely parallel those of Timberlane. The Second Circuit in Schoenbaum v. Firstbrook ${ }^{154}$ upheld the application of United States law to a Canadian corporation and its foreign directors, when corporate stockholders sought damages resulting from sales in Canada of treasury stock at market prices known, through inside information, to be less than the stock's true value. As a result of the sales, the stockholder equity was necessarily reduced, a fact reflected in lower

Anthes Imperial Ltd., 473 F.2d 515, 524 (8th Cir. 1973); Leasco Data Processing Equip. Corp. v. Maxwell, 468 F.2d 1326, 1336-37 (2d Cir. 1972). Compare Mormels v. Girofinance, S.A., 544 F.Supp. 815, 817-18 (S.D.N.Y. 1982) (United States law not applied to allegedly fraudulent acts of a Costa Rican company in Costa Rica where the only tie to the U.S. was the defendant's holding himself out as an agent of E.F. Hutton, a New York corporation, and Hutton's failure to disclose the inaccuracy. The court concluded that the fraud was "primarily foreign." In other words, no activity, significant with respect to the fraud, occurred in the United States.).

152. See also Securities \& Exch. Comm'n v. Kasser, 548 F.2d 109, 116 (3d Cir.) (expressing concern that, if the United States refused to assert jurisdiction when acts here resulted in injury abroad, other nations might also refuse jurisdiction when acts there caused injury here. If the United States in the latter situations lacked prescriptive or personal jurisdiction, such actors would "escape with impunity. By finding jurisdiction here, we may encourage other nations to take appropriate steps against parties who seek to [transport] frauds [to] the United States.”), cert. denied, 431 U.S. 938 (1977).

153. See IIT, An Int'l Inv. Trust v. Cornfeld, 619 F.2d 909 (2d Cir. 1980).

The problem of conflict between our laws and that of a foreign government is much less when the issue is the enforcement of the anti-fraud sections of the securities laws than with such provisions as those requiring registration of persons or securities. The primary interest of Luxembourg is in the righting of a wrong done to an entity created by it. If our anti-fraud laws are stricter than Luxembourg's, that country will surely not be offended by their application. If they are wcaker .... the [plaintiffs] made their choice, doubtless at least in part because of difficulty in securing personal jurisdiction in Luxembourg . . . ."

Id. at 921. This lack of potential conflict has led one commentator to call for the assertion of prescriptive jurisdiction by the United States even when the conduct of the defendant can be fairly characterized as only minimal: "The assertion of jurisdiction by an American court over a transnational fraud claim hardly interferes with the economic policies of the foreign countries. Rather, the American court is merely providing a remedy for an accepted wrong." Note, Expanding the Jurisdictional Basis for Transnational Securities Fraud Cases: A Minimal Conduct Approach, 6 FоRDнАм INT'L L.J. 308, 328 (1983) (footnote omitted). At the same time, the author assumes that a finding of prescriptive jurisdiction would not preclude a forum non conveniens dismissal.

154. 405 F.2d 200 (2d Cir.), aff'd in part, rev'd in part, 405 F.2d 215 (2d Cir. 1968), cert. dcnicd 395 U.S. 906 (1969). 
prices bid for the shares on the American market, to the financial detrinient of United States stockholders in the corporation. Since congressional intent enconipassed the protection of domestic investors in foreign corporations whose securities are listed on a domestic exchange, an assertion of prescriptive jurisdiction was proper. ${ }^{155}$

The Schoenbaum decision did not take into account Canada's interest in regulating the activities of its corporations. ${ }^{156}$ If Canada were to treat such acts more severely than does the United States, there would be no real conflict of sovereign interests, smce nothing precludes Canada from exercising concurrent jurisdiction. On the other hand, Canada presumably has no interest in coinpletely protecting fraudulent acts. Ouly if Canada's law, while proscribing the action, penalizes it less severely than does United States law, in an attempt, for example, to ease the perceived burdens of corporate decisionmaking, is there a potential conflict of interest. The ability of a government to protect its nationals, however, is necessarily linmited when those nationals act outside the country. Here, for example, the corporation was histed on the American Stock Exchange and sought United States investors. As well as satisfying the requirements for personal jurisdiction, the nature and situs of these activities are such that an apphication of the suggested balancing test also would result in the use of Urited States law.

The potential for harm to Canadian interests by apphication of United States law to regulate this specific conduct of its corporation is not great. Assuming the equivalency of sovereign interests in protecting investors and fostering ease of corporate decisionmaking, lessening liability for activities Canada agrees are improper may foster those improper activities, but that is not the purpose to be achieved. In other words, the means chosen are not particularly effective. Rehieving corporate officers and directors of such pressures as those engendered by stockholders who continually challenge corporate decisions in court by lessening the penalty for improper corporate activities does not eliminate pressure on thein to choose between proper alternative courses of action. Restrictions imposed upon the prospective plaintiffs, to assure well-founded

155. See also Des Brisay v. Goldfield Corp., 549 F.2d 133, 135 (9th Cir. 1977) (Although only one of the shareholder class was known to be a United States citizen, the United States market in shares of a United States corporation collapsed as a result of a fraudulent foreign transaction, and that effect was sufficient to sustain jurisdiction.). Compare Bersch v. Drexel Firestone, Inc., 519 F.2d 974, 989, 992 (2d Cir.) (court found that if a transaction is predominantly foreign, the applicability of United States law depends in large part upon the citizenship and residency of those affected. An adverse effect on the United States market arising from the collapse of a foreign corporation was insufficient to sustain jurisdiction.), cert. denied, 423 U.S. 1018 (1975).

156. The court did comment that if the defendants' activities also gave rise to a claim under Canadian law, the district court might decline to exercise jurisdiction under the doctrine of forum non conveniens. Schoenbaum, 405 F. $2 d$ at 209. Such a result, however, is highly unlikely. See infra note 205 and accompanying text. 
complaints, or the acceptance of indemnification by the corporation for hability resultimg from umintentional wrongdoing, are means better adapted to the achievement of the announced goal.

On the other hand, investors who purchase stock in corporations listed on a domestic exchange would lose much of the protection afforded by Umited States securities law if they lost all such protection whenever the damage caused to them resulted from activities undertaken elsewhere. Thus if Canada's competing interests had been recognized and balanced, the balancing would not have changed the prescriptive jurisdictional result. ${ }^{157}$ The achievement of United States regulatory goals does not undermine the goals of another state.

Two recent court of appeals opinions have used the rationale of cases in the area of securities law to determine the reach of the Commodity Exchange Act. ${ }^{158}$ These cases also fail to refer to the potential conflict with foreign interests caused by regulation of conduct under United States law. Tamari v. Bache \& Co. (Lebanon) S.A.L. ${ }^{159}$ was a suit brought by Lebanese citizens against a Lebanese corporation for violations of the Act, such as churning the account, accomplished through the trading of commodity futures on the Chicago Board of Trade and the Chicago Mercantile Exchange. Psimenos v. E.F. Hutton \& Co. ${ }^{160}$ involved a claim by a foreign plaintiff for fraudulent procurement and management of his commodities trading account by foreign offices of the defendant. Trading contracts that consummated transactions in the account were often executed in New York, and trading was done in domestic futures contracts on commodities exchanges in the United States.

In both cases, trading on United States exchanges supported United States regulation and, therefore, application of Umited States law. Both courts found that such conduct was sufficiently material, even though the allegedly fraudulent misrepresentations and decisions occurred abroad, since the trades were the culmination of the frauds and the direct cause of the plaintiffs' losses.

The Tamari court further justified use of United States law by argu-

157. See also Thomas, Extraterritoriality in an Era of Internationalization of the Securities Markets: The Need to Revisit Domestic Policies, 35 RuTGERS L. REv. 453, $459-60$ (1983) (arguing that it is necessary to weigh the location of the transnational transaction, the domicile of the parties, the importance to each interested country of having its law applied in a given situation, the public policies of such countries that would be furthered by application of its laws, the likelihood that another country will assert jurisdiction over the transaction, and the expeetation of the parties with respect to the applicable law); Larose, Conficts, Contacts, and Cooperation: Extraterritorial Application of the United States Securities Laws, 12 SEC. REG. L.J. 99, 122 (1984) (arguing that the concerns expressed by Professor Thomas are successfully dealt with in the context of discovery).

158. 7 U.S.C. $\$ 1$ (1982).

159. 730 F.2d 1103 (7th Cir. 1984).

160. 722 F.2d 1041 (2d Cir. 1983). 
ing that the foreign-initiated transactions on domestic exchanges caused harmful domestic effects, implicating the pricing and hedging functions of doinestic markets, artificially imfluencing prices and trading volumes, and undermining public confidence in those markets. In the securities area however, such potentially negative systemic effects have been held insufficient to sustain jurisdiction without fraudulent activity in the United States or injury to a United States investor. ${ }^{161}$ Clearly, the effect is at best de minimis with respect to any single set of transactions. Only if foreign decisions with respect to trades consummated on United States exchanges were frequently violative of United States law and not violative of the law of the decisionmaker's sovereign would the feared effect occur. The market's integrity is simply not sufficiently challenged to support the Tamari court's assertion that Congress imtended to proscribe all fraudulent conduct associated with a transaction executed on a domestic exchange-wherever undertaken and even if that conduct causes no harm to United States citizens.

Assuming that it is the conduct of the defendant in the United States, rather than any domestic effect, that forms the basis of jurisdiction, it should be noted that neither the Tamari nor the Psimenos court discussed whether the trades were significant with respect to the alleged violation or whether that requirement, found in the securities law cases, is any different from the demand that the Umited States activities be material and not merely preparatory. ${ }^{162}$ It is beyond dispute that the trades in the United States were not preparatory and did cause the loss; they were essential to the defendant's scheme. However, in those cases that applied the securities laws on the basis of Umited States activities, the activities in the United States were theniselves fraudulent. ${ }^{163}$ Here the trades were ordinary busmess transactions. The acts that made them improper all occurred abroad. Both courts nonetheless found a United States interest that would be harmed if United States law were not used to regulate the defendants' foreign activities and, therefore, a congressional intent under the Conımodity Exchange Act to regulate those activities: United States markets should not be used as a base to consuniniate fraudulent schemes concocted abroad.

Assuining that such an interest is present, since the donestic transaction itself was not fraudulent and the foreign fraudulent acts had no appreciable effect in the United States, inevitably there will be other sovereigus with strong interests in regulating the defendants' conduct. The courts in each case failed to recognize those interests or to balance the harm caused to those interests by United States regulation against the

161. See supra note 155.

162. See supra note 151.

163. See cases cited in supra notes $150-53$ and accompanying text. 
potential harm caused to United States interests by a failure to regulate. Consequently, not all of the "public factors" of forum non conveniens were taken into account.

In fact, this expanded understanding of prescriptive jurisdiction has led the Commodity Futures Trading Coinınission to adopt forum non conveniens as a method of disnissing the kind of claims exemplified by Tamari and Psimenos. ${ }^{164}$ Use of the doctrine on these facts is appealing, but its appeal is a result of the courts' failure to complete properly its prescriptive jurisdictional analysis. Factors of convenience, location of witnesses and evidence, and other private factors that the doctrine enconipasses should be considered in the context of personal jurisdiction. In Psimenos, they would have been insufficient to challenge that jurisdiction, since the defendant, which was sued in the Southern District of New York, had its principal place of business there. Furthermore, a proinotional pamphlet, on which the plaintiff allegedly relied, emanated from the defendant's New York office, thus in some small way tying the claim to local activities. In Tamari, personal jurisdiction over the Lebanese defendant was presuniably premised on its placement with a Delaware corporation of orders then executed in Illinois, in whose district court suit was brought. The sufficiency of this contact apparently was not questioned, but perhaps it should have been. The defendant itself never acted in the forun, and the analogous indirect activity to achieve the imprimatur of the Supreme Court, utilization by a manufacturer of a stream of coinmerce, is inapposite-the injury occurred in Lebanon-unless one accepts the Fifth Circuit's description of the injury as one to the Chicago exchanges. ${ }^{165}$

If activity that violates United States law occurs in the United States, or if activity abroad that is not sanctioned by the foreign sovereign causes harm in the United States, the outcome of balancing harin caused to sovereign conipeting interests by regulation or failure to regulate may be foreordained. In Tamari and Psimenos it is not. If courts are willing to expand the situations in which sufficient activities or effects have occurred here beyond those accepted in the securities cases, the logic of Timberlane compels then to consider as well the interests of foreign sovereigns. The extent to which those interests would be adversely affected balanced against the United States interest that would be harined should United States law not be applied will determine the issue of prescriptive jurisdiction. ${ }^{166}$ As in the antitrust context, determi-

164. CFTC Policy Statement on Extraterritorial Respondents' Activities, 16 Sec. Reg. \& L. Rep. (BNA) 694, 695 (Apr. 20, 1984).

165. See supra note 41. See generally Part I, supra.

166. Without specifically adopting a balancing test, the few cases that have discussed the reach of the Lanham Act, 15 U.S.C. $\$$ 1051-1127 (1982), have considered the competing interests of foreign governments in the areas of trademark and unfair competition. Steele v. Bulova Watch Co., 
nation of that issue will necessitate reference to the interests of the chosen and alternative fora and will include consideration of those forum non conveniens factors not already addressed by the personal jurisdiction analysis. Again, the doctrine is left without any but a redundant role to play.

The other body of United States law that is frequently alleged to regulate conduct with substantial foreign connections is that regulating adiniralty, primarily the Jones Act. ${ }^{167}$ Literally, that Act grants to any seaman injured or killed anywhere in the course of his employment a claim against his einployer cognizable in United States courts, ${ }^{168}$ assuming, of course, that personal jurisdiction can be obtained over the defendant. ${ }^{169}$ The scope of the Act, then, seenis to parallel the scope of the admiralty jurisdiction of the federal courts, which enconipasses all claims arising under general niaritime law. ${ }^{170}$ Just as the doctrine of forum non

344 U.S. 280, 289 (1952) (Act applicable to conduct of United States citizen in Mexico that reflected adversely upon plaintiff's trade reputation in markets cultivated by it; the Court noted that Mexican courts had nullified the defendant's Mexican registration of "Bulova" and that, therefore, relief under United States law would not impugn foreign law); American Rice, Inc. v. Arkansas Rice Growers Coop. Ass'n, 701 F.2d 408, 415-16 (5th Cir. 1983) (Act applicable to defendant's conduct in Saudi Arabia, where defendant argued it liad a concurrent riglit to use of plaintiff's mark; the court stated that it would not be an affront to Saudi Arabia to enjoin injury to plaintiff's Saudi commerce absent a determination by a Saudi court that defendant was entitled to use the mark and that the mark did not infringe plaintiff's mark); Vanity Fair Mills, Inc. v. T. Eaton Co., 234 F.2d 633, 641 (2d Cir.) (Act not applicable to activities of foreign national in its lome country under presumably valid trademark registration there; the court distingnished Bulova in part because of the lack of any potential conflict in that case with Mexican trademark rights), cert. denied, 352 U.S. 871 (1956).

167. 46 U.S.C. $\S 688$ (1982).

168. Any seaman who shall suffer personal injury in the course of lis employment may, at his election, maintain an action for damages at law, with the right of trial by jury, and in such action all statutes of the United States modifying or extending the common-law right or remedy in cases of personal injury to railway employees shall apply; and in case of death of any seaman as a result of any such personal injury the personal representative of such seaman may maintain an action for damages at law with the riglt of trial by jury, and in such action all statutes of the United States conferring or regulating the right of action for death in the case of railway employees shall be applicable. Jurisdiction in such actions shall be under the court of the district in which the defendant employer resides or in which his principal office is located.

46 U.S.C $\S 688$ (a) (1982).

169. To the extent that jurisdiction over the defendant is limited by the arguments suggested in Part $I$, supra, the number of claims with significant foreign contacts that could be maintained under the Act is limited. Seizure of the vessel on which the injury oceurred, and the consequent assertion of in rem jurisdiction, is not an issue in this statutory context, since the Jones Act claim is in personam. Lauritzen v. Larsen, 345 U.S. 571, 574 (1953). But the attachment of any property of the defendant, as well as the assertion of jurisdiction based upon continuous but unrelated activity in the forum, may still be mistakenly upheld, and that mistake may expand the number of situations in which prescriptive jurisdiction is an issue.

170. Langnes v. Green, 282 U.S. 531, 544 (1931); The Belgenland, 114 U.S. 355, 367 (1885); The Maggie Hammond v. Morland, 76 U.S. (9 Wall.) 435, 457 (1869); Sosa v. M/V Lago Izabal, 736 F.2d 1028, 1031 (5th Cir. 1984). This recognition of jurisdiction over claims that arise under the "common law of nations," whenever the injuries occur on navigable waters in connection with the navigation of a vessel, is unique to the maritime context. In all other situations, the substantive law 
conveniens arose to limit admiralty jurisdiction, however, so too judicial interpretation of congressional imtent and, to a lesser extent, of due process, has limited the situations in which a plaintiff can actually state a claim under statutory admirality law. Although the bases of disniissal and the weight accorded relevant contacts differ in the two instances, the same factors dominate both decisions. ${ }^{171}$

For more than thirty years, the controlling statement of those factors has been the opinion of the Supreme Court in Lauritzen v. Larsen, ${ }^{172}$ which discusses the applicability of the Jones Act to a claim by a Danish seaman against the Danish owner of a Danish flag ship for damages suffered by him as a result of an accident in Cuba. While the opinion is most frequently cited for its hist of contacts relevant to the determination of prescriptive jurisdiction, its emphasis on the importance of considering the impact that an assertion of United States jurisdiction will have on the imterests of other sovereigns is central to its analysis.

Noting that the Jones Act was not written "on a clean slate," 173 the Court characterized the traditional task of United States courts settling common law maritime conflicts as "reconciling our own with foreign interests and ... accominodating the reach of our own laws to those of other maritime nations." 174 Such reconciliation and accommodation, no less necessary when the law is statutory, is achieved, the Court continued, by

ascertaining and valuing points of contact between the transaction and

that is applied to a controversy must spring from an appropriate exercise of some identified sovereign's authority. The determination that such an exercise is appropriate rests, of course, on the existence of certain contacts between the litigation, the parties, and the source of law. Such contacts are not necessary in the maritime context, which is undoubtedly why the doctrine of forum non conveniens, which necessitates consideration of those contacts, was developed there, and is currently used when claims are brought under the general maritime law or under the regulatory law of a foreign sovereign. See, e.g., Sosa, 736 F.2d at 1031. As noted in the text, the Lauritzen court failcd to distinguish the jurisdictional from the discretionary decision and emphasized the need to consider foreign interests. See infra notes 172-77 and accompanying text. If the analytical distinction is retained, forum non conveniens may still be the only way in which those interests may be addressed. However, if in rem jurisdiction is no longer valid absent minimum contacts between the defendant and the forum and if in personam jurisdiction is generally available only where the plaintiff's claim is related to the defendant's forum activity, situations in which dismissal on the grounds of forum non conveniens would be proper will disappear.

171. See Gkiafis v. Steamship Yiosonas, 387 F.2d 460 (4th Cir. 1967); Anastasiadis v. S.S. Little John, 346 F.2d 281 (5th Cir. 1965), cert. denied, 384 U.S. 920 (1966).

172. 345 U.S. 571 (1953).

173. Id. at 577 .

174. Id. In at least one, somewhat related, situation, such reconciliation and aecommodation is not thought necessary: the reach of United States criminal jurisdiction may properly encompass nonresident aliens on stateless vessels on the high seas, even without a demonstrable nexus between the allegedly illegal activities of those defendants and the United States. See, e.g., United States v. Alvarez-Mena, 765 F.2d 1259, 1263-67 (5th Cir. 1985) and cases cited therein. It is interesting to note, however, that in that case Coast Guard personnel cleared their intent to board the vessel with Honduras, the country whose fiag the vessel spuriously claimed. 
the states or governments whose competing laws are involved. The criteria, in general, appear to be arrived at from weighing of the significance of one or more connecting factors between the shipping transaction regulated and the national interest served by the assertion of authority. ${ }^{175}$

The court listed seven factors ${ }^{176}$ that are to be used to determine both the nexus between the United States and the claim and the significance of that nexus in light of the competing interests of otler nations in regulating the same conduct. ${ }^{177}$

The Court reiterated the dual nature of the prescriptive jurisdiction inquiry six years later in Romero $v$. International Terminal Operating Co. ${ }^{178}$ Unfortunately, that acknowledgement was missing in a still later decision in 1970, Hellenic Lines Ltd. v. Rhoditis. ${ }^{179}$ The Rhoditis court focused on United States contacts alone. Some lower federal courts have taken this to inply that prescriptive jurisdiction can be determined by reference only to the national interests of the United States. ${ }^{180}$ Currently when a court concludes that the Jones Act ought not apply to a transaction, or that a claim brought under the general maritime law ought to be dismissed, reference may be made to the interests of other nations, but reference to those interests is not assured even then, ${ }^{181}$ and otlierwise is infrequent.

Rhoditis upheld a foreign plaintiff's claim against a foreigu corporate shipowner under the Jones Act for injuries sustained by the plaintiff in the Port of New Orleans. Prescriptive jurisdiction was premised not on the place of the injury, ${ }^{182}$ but on the defendant's Umited States base of

175. Lauritzen, 345 U.S. at 582.

176. Those factors are (1) place of the wrongful act, (2) law of the flag, (3) allegiance or domicile of the injured, (4) allegiance of the defendant shipowner, (5) place of the contract, (6) inaccessibility of a foreign forum, and (7) the law of the forum. Id. at 583-92.

177. But see McCulloch v. Sociedad Nacional, 372 U.S. 10 (1963), in which the court rejected balancing the relative weight of United States and foreign contacts as a justification for the use of United States law. In determining whether Congress intended the National Labor Relations Act, 29 U.S.C. $\$ \S 151-169$ (1982), to apply to the foreign crew of a foreign flag vessel owned by a foreign corporation in United States waters, the Court noted that, "the [National Labor Relations] Board's assertion of power to determine the representation of foreign seamen aboard vessels under foreign flags has aroused vigorous protests from foreign governments and created international problems for our Government." McCulloch 372 U.S. at 16-17. The Court reasoned that the use of United States law when the balance of contacts favored the United States would disturb traditional maritime law, which calls for use of the law of the flag, as well as our international relations. Absent any legislative history to the contrary, the Court refused to find such a congressional intent and held the Act inapplicable. See also Benz v. Compania Naviera Hidalgo, 353 U.S. 138 (1957) (respecting the application of the Taft-Hartley Act to picketing by foreign seamen serving under foreign articles in a U.S. port).

178. 358 U.S. $354,382-83$ (1959).

179. 398 U.S. 306 (1970).

180. See, e.g., Moncada v. Lemuria Shipping Corp., 491 F.2d 470 (2d Cir.), cert. denied, 417

U.S. 947 (1974); Bartholomew v. Universe Tankships, Inc., 263 F.2d 437 (2d Cir. 1959).

181. See, e.g., Nunez-Lozano v. Rederi, 634 F.2d 135 (5th Cir. 1980).

182. Rhoditis, 398 U.S. at 308-10. 
operations. ${ }^{183}$ The Court reasoned that not to subject such a shipowner to the obligations and responsibilities of the Jones Act would be to grant it an advantage over United States citizens engaged in similar activities.

The contacts with Greece, which included that nation's status as both plaintiff's and defendant's sovereign, the nation whose flag the defendant flew, and the nation in which the plaintiff's employnient contract was executed, were characterized by the niajority as "minor weights in the scales compared with the substantial and continuing contacts that this alien owner has with this country." 184 Why those foreign contacts were "minor" is nowhere explamed. It was left to the three dissenting justices to evaluate the United States contacts in light of the purposes that underlie the Jones Act-the first step in the suggested balancing approach. If the law of the flag is not to govern, the dissent maintained, there must be a "heavy counterweight," found only if regulation of the defendant's conduct under the Act would further congressional purposes. ${ }^{185}$

Since the granting of a particular reniedy, rather than the regulation of commerce or the creation of a standard of conduct, is the policy behind the Act, it is the plaintiff's relationship to the United States, not the defendant's, that ought to be determinative. ${ }^{186}$ In terms of the analysis suggested in the antitrust context, the interest of the United States in adjusting the risk of loss between mdividuals is not harmed by failure to apply the Jones Act if the plamtiff has no tie to this country. On the other hand, if Greek law expressed a similar interest and yet were not applied

183. Id. at 309-10. This concern with the defendant's base of operations had been foreseen by a number of lower courts in the years after Lauritzen and was, perhaps, most cogently expressed in Pavlou v. Ocean Traders Marine Corp., 211 F. Supp. 320, 324-25 (S.D.N.Y. 1962); see also Southern Cross Steamship Co. v. Firipis, 285 F.2d 651 (4th Cir. 1960), cert. denied, 365 U.S. 869 (1961). Interestingly, a recent case upheld a district court's finding that the current base of operations of Hellenic Lines, the Rhoditis defendant, was not the United States and that, therefore, the Jones Act did not apply to the death in Virginia of a Greek seaman. In light of the lapse of time since the Rhoditis decision, collateral estoppel did not preclude the defendant from alleging and demonstrating a foreign base. Dracos v. Hellenic Lines, Ltd., 762 F.2d 348 (4th Cir.), cert. denied, 106 S. Ct. 311 (1985).

Given the fact that plaintiffs frequently sue not only the corporate shipowner but also its corporate parent, it is necessary to emphasize that the base of operations with which a court should concern itself is logically that of the owner-subsidiary, at least unless parental control is great and relevant. Needham v. Phillips Petroleum Co. of Norway, 719 F.2d 1481 (10th Cir. 1983).

184. Hellenic Lines Ltd. v. Rhoditis, 398 U.S. 306, 310 (1970).

185. Id. at 313.

186. Cf. Symonette Shipyards, Ltd. v. Clark, 365 F.2d 464, 467 (5th Cir. 1966), cert. denied, 387 U.S. 908 (1967). But see Voyiatzis v. National Shipping \& Trading Corp., 199 F. Supp. 920, 924 (S.D.N.Y. 1961) (Greek seaman's claim under Jones Act not dismissed on grounds of forum non conveniens when injuries were sustained in Boston, the defendant corporation's actual allegiance was to the United States, and the Liberian flag reflected only nominal allegiance, even though the plaintiff's contract called for the application of Greek law in Greece). 
to conduct aboard a Greek flagship where both parties were Greek nationals, Greece's interest would be severely undermined.

Although Rhoditis has led at times to the regulation of conduct under United Stated law when more traditional factors would have found it inapplicable, ${ }^{187}$ a Umited States base of operations has not always sustained jurisdiction ${ }^{188}$ or precluded reference to foreign interests. In particular, injuries that occur on nontraditional maritime vessels, such as semisubmersible drillimg rigs, have prompted a reevaluation of the significance of such contacts as the place of the accident, the allegiance of the seaman, and the place of the contract. ${ }^{189}$ In this context, the interest of a foreign sovereign in controlling exploration off its coast is clear and occasionally mentioned. ${ }^{190}$

Balancing is imphicit in the weight accorded different contacts-it ought to be exphicit. Substantiahty, like signiflcance, cannot be determined in a vacuum, but its determination need not force courts to choose between important goals. Here, as in the antitrust context, the issue

187. See, e.g., Szumlicz v. Norwegian Am. Line, Inc., 698 F.2d 1192, 1195-96 (11th Cir. 1983); Fisher v. The Agios Nicolaos V, 628 F.2d 308, 316-17 (5th Cir. 1980), cert. denied, 454 U.S. 816 (1981) (the place of injury was also the United States, but that factor, according to Lauritzen, is usually entitled to little weight); Antypas v. Cia. Maritima San Basilio, 541 F.2d 307 (2d Cir. 1976), cert. denied, 429 U.S. 1098 (1977).

188. See, e.g., De Oliveira v. Delta Marine Drilling Co., 707 F.2d 843 (5th Cir. 1983); Fitzgerald v. Texaco, Inc., 521 F.2d 448 (2d Cir. 1975), cert. denied, 423 U.S. 1052 (1976).

189. See Vaz Borralho v. Keydril Co., 710 F.2d 207 (5th Cir. 1983), denying rehearing and rehearing en banc to 696 F.2d 379 (5th Cir. 1983); Chiazor v. Transworld Drilling Co., 648 F.2d 1015 (5th Cir. 1981), cert. denied, 455 U.S. 1019 (1982); Phillips v. Amoco Trinidad Oil Co., 632 F.2d 82 (9th Cir. 1980), cert. denied, 451 U.S. 920 (1981).

190. See, e.g., Phillips v. Amoco Trinidad Oil Co., 632 F.2d at 88-89; Zekic v. Reading \& Bates Drilling Co., 536 F. Supp. 23, 25-26 (E.D. La. 1981), aff'd in part, vacated in part and remanded, 680 F.2d 1107 (5th Cir. 1982). The Phillips court specifically rejected the holding of an earlier Second Circuit case, Bartholomew v. Universe Tankships, Inc., 263 F.2d 437 (2d Cir.), cert. denied, 359 U.S. 1000 (1959). Utilizing the "substantial contacts" language that the Supreme Court later adopted in Rhoditis, and which Timberlane criticized severely, Bartholomew had praised its "simple formula" for obviating the need "to consider and 'weigh' the contacts that do not exist [or] to go through any process of balancing one set of facts that are present against another set of facts that are absent, without any sure guide as to how the balancing is to be done." 263 F.2d at 441 . Phillips agreed that Lauritzen did not require the court to balance between present and absent contacts-but then, that is not the balance that Lauritzen advocated. Rather, it is a balancing of United States contacts and those of an alternative sovereign, all of which are "present," that is necessary to determine "substantiality" in light of interests to be served by various bodies of law. Accord, Vaz Borralho v. Keydril Co., 696 F.2d 379, 390 (5th Cir. 1983). Unfortunately, Bartholomew was not an aberrational decision in the Second Circuit. See Moncada v. Lemuria Shipping Corp., 491 F.2d 470 (2d Cir.), cert. denied, 417 U.S. 947 (1974). In Moncada, since the undisputed base of operations of the defendant corporations was the United States, and since all of their stockholders and officers were citizens of the United States, it is likely that New York, or some other state, was the defendants' principal place of business. Although such "substantial" contact may justify personal jurisdiction and obviate the need to consider convenience to the defendant that had claimed citizenship in the forum, it fails to address the foreign effects of an assertion of prescriptive jurisdiction. 
ought to be the extent to which the goals of each sovereign will be hindered by the regulation of conduct under another's law.

Absent such specific identification of the national interests at stake and the degree to which each will be hindered by use of another forum's law, the court is reduced to conclusory statements about the domain of the controversy or its "local" nature. Furthermore, the reason for the inquiry is easily lost in tallying up contacts between the forum, the defendant, and the hitigation, without reference to why those contacts are relevant.

The Third Circuit's decision in Chirinos de Alvarez v. Creole Petroleum Corp. ${ }^{191}$ exemplifies the problem, which, after all, is at the heart of most criticism of Timberlane. Four Venezuelan seaman, serving under a Venezuelan contract, were killed in Venezuelan waters. Their widows sued the corporate owner of the Venezuelan flag-launch and its corporate parent. Both defendants were mcorporated in Delaware, but the launch owner's principal place of business was Venezuela, and its parent's was New York. All "contacts" but the allegiance of the shipowner were clearly Venezuelan. Yet to conclude, as did the court, that United States interests "pale" in the light of "Venezuelan concerns" is to do a disservice to the concept of balancing. ${ }^{192}$ Presumably, for instance, if the thrust of United States law were to regulate the activities of its citizens, whether they act here or abroad, and the thrust of Venezuelan law were the same, the shipowner's allegiance would be of critical importance. The facts might make it difficult to determine whether its business in Venezuela or its incorporation in Delaware gave Venezuela or the United States the greater claim to injury to its interests absent use of its own law. Perhaps the degree of the second defendant's control of the launch owner would help resolve the dispute. It is clear that the balance favors Venezuela only if it is assumed that the interest protected by the competing laws is the compensation of seamen, the protection of national waters, or the regulation of national flag vessels. ${ }^{193}$

In determining the existence of prescriptive jurisdiction, the court should clearly identify and discuss the effect of an assertion of such jurisdiction on the competing sovereign interests of concerned fora. In the

191. 613 F.2d 1240 (3d Cir. 1980).

192. Id. at 1247.

193. See supra note 186 and accompanying text.

After finding that the Jones Act was inapplicable, the trial court had dismissed the case under Federal Rule of Civil Procedure 12(b)(6), for failure to state a claim upon which relief could be granted, as well as under the doctrine of forum non conveniens. The second ground was clearly unnecessary. On the facts, it made little difference since, absent complete diversity, the plaintiffs could not allege subject matter jurisdiction with respect to a claim arising under foreign law. Had complete diversity existed, however, and had the plaintiffs sought leave to amend their complaint to state such a claim, the suit should have been retained. See infra note 205 and accompanying text. 
context of admiralty, as in the contexts of antitrust and securities laws, this jurisdictional recognition of interests other than those of the forum will satisfy those policies that underly the "public factors" of foruin non conveniens.

\section{B. Application of State Law}

The extraterritorial application of state law, when the alternative interested foruin is another state, raises problenis that parallel those raised in federal prescriptive jurisdiction decisions. The prescriptive jurisdictional authority of both systems is restrained by the due process clauses of the Constitution. The states are additionally restrained by the full faith and credit clause. ${ }^{194}$

Currently, only one ineinber of the Supreme Court, Justice Stevens, interprets the full faith and credit clause as imposing upon a state's choice of law doctrine a requirement that use of the foruin law not unjustifiably infringe upon the legitimate interests of another state. ${ }^{195}$ Such a concern, of course, may be expressed in the national context as part of the prescriptive jurisdictional analysis. ${ }^{196}$ The rest of the Court equates the restraint of that clause with the restraint imposed upon states by due process. The use of foruin law to regulate conduct is justifiable if the forum has "significant" contacts with the parties and the underlying transaction, such that the forum has recognizable interests in the outcome of litigation arising from the conduct. The existence of such contacts assures that regulation by the forum will be neither arbitrary nor fundainentally unfair and that the legitmiate expectations of the parties will not be ignored. ${ }^{197}$

The inajority, however, lias not explained how it is possible in this context to deterinine the significance of foruin contacts without reference to contacts between the parties, the hitigation, and other fora. After all, in the context of adıniralty, where "siguificant" or "substantial" foruin contacts are also required, the Lauritzen Court found it necessary to refer to coinpeting interests of other fora in order to deterinine coinpliance with that prescriptive jurisdictional prerequisite. ${ }^{198}$

Only where the forum has virtually no contact with the dispute is it logically possible to characterize its contacts as "insignificant" without reference to the interest of an alternative forum in the use of its own law.

194. See supra note 12.

195. See Allstate Ins. Co. v. Hague, 449 U.S. 302, 320-23 (1981) (Stevens, J., concurring); see also Phillips Petroleum Co. v. Shutts, 105 S. Ct. 2965, 2982, 2987 (1985) (Stevens, J., concurring in part and dissenting in part).

196. See supra note 11 .

197. Hague, 449 U.S. at 308.

198. See supra notes $172-77$ and accompanying text. 
In the judgment of six members of the court, Phillips Petroleum Co. v. Shutts ${ }^{199}$ presented this rare situation. A class action had been filed in a Kansas state court against Phillips, on behalf of all those who had owned an interest in lands leased by Phillips that entitled them to a royalty payment tied to the purchase price of natural gas extracted from those lands and sold by or through Phillips. Phillips had been permitted to charge a proposed imcreased price prior to approval by the relevant federal commission; it was to retain the increase if the commission approved the new price, but was to refund it with interest to the purchasers if the commission demed the request. At the sane time, Phillips paid royalties based upon its old purchase price pending commission approval of the increase. Once approval was obtamed, Phillips reimbursed royalty owners the difference between the old and actually owing royalties, but did not pay those owners any interest on the money, of which it had had the use durmg the time of the commission deliberations. The action sought to recover interest at the saine rate Phillips would have paid to its purchasers had its increase been denied.

The Kansas Supreme Court approved use of Kansas law to determine Phillips' hability to the entire class, and the United States Supreme Court reversed. Noting a potential conflict between Kansas law and that of Texas, where much of the leased land was located, and Oklahoma, which was also a source of many of the leases and Phillips's principal place of business, the Court found that Kansas had "significant contact" only with respect to claims brought by Kansas royalty owners or that arose from leases on Kansas land. Its use of its own law with respect to other claims was constitutionally impermissible.

Justice Stevens dissented with respect to the prescriptive jurisdictional issue. Arguing that the concerns implicated by the full faith and credit clause and the due process clause are distinct, he began by closely analyzing Kansas's analysis of Texas and Oklahoma law to determine whether the potential conflict found by the majority actually existed. $\mathrm{He}$ concluded that it did not; the other states were either in agreement with Kansas or had not reached the issues raised in this case. Thus, use of Kansas law did not impair the legitimate interests of any other state and was not precluded by the full faith and credit clause. Neither was the use of Kansas law fundamentally unfair or arbitrary. No party had a legitimate expectation of a legal result at the time the claims arose; such an expectation was unjustifiable in light of the lack of precedent. Therefore, even though Kansas had no contact with the claims of nonresidents regarding non-Kansas land, nothing in the Constitution precluded use of its law. As a result, the difficulties raised by the majority's conclusion-

199. 105 S. Ct. 2965 (1985). 
possible lack of class commonality or adequate representation, in addition to the nearly impossible task imposed upon the trial court of determining how each state would resolve a matter it had not thought aboutcould be easily avoided.

Of course, most of those difficulties could also be avoided by choosing Oklahoina law to regulate all claims-presumably permissible since it was Phillips' principal place of business- and then interpreting that law in accordance with Kansas precedent.

To the extent that, on remand, Kansas could achieve the same result by good faith reference to and interpretation of the law of another state or states, the opinion in Phillips may constitute a tempest in a teapot. But the case reinains theoretically iniportant for two reasons. First, the dispute between the majority and Justice Stevens centered upon the degree of actual conflict between state laws that is sufficient to trigger a constitutional choice of law analysis. Second, Justice Stevens's opmion properly focuses attention on a question the majority ignores: why does the existence of "siguificant" contacts justify use of local law? His exclusive emphasis on the legitiniate expectation of a legal result may be misplaced, but he is certainly correct that the Constitution has not been violated if no other state interests are impaired and if the parties are not treated unfairly. It is the protection afforded states and litigants that the Court should focus upon, not a word formula, which inay or may not reflect that protection.

In situations other than that presented by Phillips, the forum is usually adjudged to have some relevant contact with the dispute. In those cases the determination of "significance," in the absence of any consideration of the interest of an alternative forum in the use of its own law, becoines little more than a tallying of contacts. Little if any attention is given to their individual weight, reason for relevance, or the point at which the sum is sufficient to be pronounced significant.

For example, in Allstate Ins. Co. v. Hague, ${ }^{200}$ a Minnesota resident sued in Minnesota state court as the state-appointed personal representative of her deceased husband. She sought a declaratory judgment as to the defendant's liability on an insurance policy issued by it in Wisconsin to her husband at a time when they both lived in Wisconsin. She had moved to Minnesota, for reasons unconnected to the litigation, after her husband's death in a car accident in Wisconsin.

Five Justices held that it was constitutionally perinissible for Minnesota to apply its own law. Justice Brennan's plurality opinion found sufficient contact because the deceased had worked in Minnesota, Allstate was present and doing business in the state, its alleged obligation was to a

200. 449 U.S. 302 (1981). 
current resident of Minnesota, and Allstate could not have legitimately expected that only Wisconsin law would apply to claims under the contract.

Justice Powell, writing for the three dissenting Justices, emphasized that in order to determine whether the contacts noted by the majority were "significant," it was necessary to recall why the requirement was imposed: contacts are "significant" if they "form a reasonable link between the litigation and a state policy."201 Here, he maintained, no policy of Minnesota was implicated. The postaccident residence of the plaintiff was irrelevant; the fact that Allstate did business there gave the state an interest in its conduct only to the extent that its conduct related to property, persons, or contracts in the forum; and the Minnesota employment of the deceased, while it might provide a link to some state policies, provided no link to any legitimate policy with respect to an accident in Wisconsin totally unrelated to his employment status.

Justice Stevens's concurrence also focused on why contacts with the forum were necessary to sustain prescriptive jurisdiction, although he agreed with Justice Brennan's conclusion. He found that an assertion of jurisdiction did not impinge upon Wisconsin's sovereignity, nor could the parties advance the argument of unfair surprise as it was clear from the beginning that the contract might be subject to interpretation under otler law. He agreed with the dissent, however, that the plaintiff's residence and the deceased's employment situs were not determinative of the due process issue. ${ }^{202}$ The dissent disagreed with Stevens's reference to the imterests of Wisconsm, commenting that such scrutiny "may draw this court back into the discredited practice of weighing the relative interests of various States in a particular controversy." 203

Justice Stevens's position in Hague, that the full faith and credit clause requires that the state consider the legitimate interests of other states, is appealing. As he has pointed out, the primary interests served by the two constitutional clauses are distinct. The full faith and credit clause expresses a federal concern that each state respect the sovereignty of its sister states, while the due process clause is designed to protect the litigants' interest in a fair adjudication of their rights. ${ }^{204}$ Not surprisingly, the majority's justification for use of forum law focuses on the latter interest, ignoring the former.

Nothing in the position of the Court precludes states from consider-

201. Id. at 334.

202. Id. at 331 .

203. Id. at 339 n.6. For a discussion of the propriety of an assertion of personal jurisdiction over Allstate, which led at least the plurality to conclude that use of Minnesota law could not constitute unfair surprise, see supra note 109 , and accompanying text.

204. Allstate Ins. Co. v. Hague, 449 U.S. 302, 320 (1981). 
ing the competing interests of alternative fora in crafting their own choice of law rules, however, or from deciding, under those rules, not to assert constitutionally permissible prescriptive jurisdiction. Due process would prevent a state from choosing to apply the law of another state that lacked significant contacts with the hitigation, but, assuming the existence of two fora constitutionally free to assert prescriptive jurisdiction, the chosen forum could certainly utilize the law of its "competitor" to resolve the dispute. Thus, whatever interest a state may have in deferring to the claims of another state for use of its law can be readily accominodated in its own choice of law doctrine. The doctrine of forum non conveniens is not necessary to permit consideration of the interests of an alternative state.

\section{Conclusion: A CONTINUING ROLE FOR Forum NON CONVENIENS?}

In light of the suggested personal and prescriptive jurisdiction analyses, a number of jurisdictional permutations are possible.

When the forum chosen by the plaintiff lacks personal jurisdiction over the defendant, of course, forum non conveniens is not a relevant issue; the suit will be dismissed for lack of that jurisdiction. If, on the other hand, the chosen forum can properly assert both personal and prescriptive jurisdiction, dismissal on grounds of forum non conveniens is currently rare. ${ }^{205}$ Contacts with the forum must be related to the plaintiff's claim since such related contacts are indispensable to prescriptive

205. Usually if fornm law is applicable, the suit is retained. Certainly, if the alternative fornm were to utilize its own law, retention would be totally logical. Only by retaining the suit can the interests served by forum law be protected, and it is recognition of those interests, either alone or in comparison to the interests of other fora, that underlies the prescriptive jurisdiction decision in the first place. Diaz v. Humboldt, 722 F.2d 1216, 1217 (5th Cir. 1984) (if Jones Act applicable, suit should be entertained); accord, Pereira v. Utah Transport, Inc., 764 F.2d 686 (9th Cir. 1985), cert. denied, $106 \mathrm{~S}$. Ct. 1253 (1986), and cases cited therein, id. at 688. But see Cruz v. Maritime Co. of Philippines, 702 F.2d 47, 48 (2d Cir. 1983) (applicability of Jones Act does not foreclose dismissal in light of "exceptional circumstances such as the application of the abstention doctrine or ... the equitable principle of forum non conveniens."). See also Industrial Inv. Dev. Corp. v. Mitsui, 671 F.2d 876 (5th Cir. 1982), vacated on other grounds, 460 U.S. 1007 (1983) (if plaintiff's claim is congizable under United States antitrust laws, forum non conveniens is inappropriate, citing United States v. National City Lines, 334 U.S. 573 (1948), which held the doctrine inapplicable when the alternative forum was another United States court); accord, Laker Airways Ltd. v. Pan Am. World Airways, 568 F. Supp. 811 (D.D.C. 1983).

This assumption, however, would seem to be confined to situations in which it is the prescriptive jurisdiction of the United States that dismissal would defeat. The fact that state law could be properly used by the chosen forum has not been considered by the Supreme Court to prevent dismissal of a suit on the grounds of forum non conveniens, although it was clear that the alternative forum would apply its own law instead. This result presumably conflicts with the reasons that made application of state law proper in the first place. Piper Aircraft Co. v. Reyno, 454 U.S. 235 (1981). Indeed, the Court did not even comment on the loss of prescriptive jurisdiction. See supra notes 28-39 and accompanying text. Of course, one argument that this Article makes is that Piper was wrongly decided under the traditional forum non conveniens doctrine. 
jurisdiction and may sustain personal jurisdiction. In this situation, convenience has or should have been considered in the personal jurisdiction analysis or it is outweighed by the forum citizenship of the defendant. The assertion of prescriptive jurisdiction means, by hypothesis, that the forum itself is interested in the litigation, and either its interest outweighs that of alternative fora or those competing interests are not deemed relevant by the court.

When the forum has personal but not prescriptive jurisdiction, forum non conveniens is most appealing. If the forum lacks prescriptive jurisdiction because it has no "significant" contacts with the dispute, the contacts between the forum and the defendant that support personal jurisdiction are usually unrelated to the plaintiff's claim.

In this situation, if jurisdiction over the defendant is proper because of citizenship, convenience is not a necessary part of the underlying personal jurisdiction analysis and the doctrine of forum non conveniens arguably remains necessary as a vehicle to permit consideration of it. Not only may the forum be highly inconvenient for witnesses and for some corporate defendants, but also retention of litigation that is to be governed by foreign law imposes the sort of systemic burden on the court and possibly on local juries that the Suprenie Court rejected in Gilbert. ${ }^{206}$ As noted above, however, ${ }^{207}$ the nature and substantiality of the citizensovereign relationship justifies the burden imposed upon the defendant and ought to justify the systemic burden as well. The sovereign derives benefits from its citizens, as do citizens from the sovereign, and fairly bears the responsibility for providing a forun in which clainıs against its citizens may be heard. ${ }^{208}$ Furthermore, given the citizenship of the defendant, there may be a community interest in the litigation.

It is in this context that courts most frequently wax eloquent about the interests of alternate fora. ${ }^{209}$ But those interests have already been recognized in the decision to utilize foreigu law, and further reference to them to justify dismissal of the suit is reasonable only if use of foreign law alone is insufficient to protect them. Given the fact that the plaintiff,

206. See supra note 89 and accompanying text.

207. See supra text accompanying notes 87-98.

208. Such systemic burdens, of course, may ordinarily be considered in the personal jurisdictional analysis since the nature and quality of the defendant's activities in the forum are to be considered in relationship to the fair and orderly administration of the laws. International Shoe Co. v. Washington, 326 U.S. 310, 316 (1945). See supra note 113 and accompanying text. But just as factors of convenience to the parties and witnesses fail to outweigh the benefits of citizenship to the defendant, so too factors of systemic convenience fail to defeat jurisdiction. After having recognized but rejected both burdens as reasons for denying jurisdiction, there is no point in resurrecting them to achieve a similar result under a different name.

209. See, e.g., Panama Processes, S.A. v. Cities Serv. Co., 650 F.2d 408, $413-15$ (2d Cir. 1981); Calavo Growers v. Generali Belgium, 632 F.2d 963, 967 (2d Cir. 1980) (defendants were foreign insurance underwriters doing business in New York), cert. denied, 449 U.S. 1084 (1981). 
generally a citizen or subject of the other sovereign, chose to litigate elsewhere, the only competing interest not served by use of foreign substantive law-the political interest in resolving a local dispute locallyshould not suffice to sustain dismissal. ${ }^{210}$

If the defendant is not a citizen of the forum, but personal jurisdiction is nonetheless proper because the defendant is engaged in continuous though unrelated activities there and the litigation is no more burdensome than it would be in the alternative forum, the calculus changes but the result does not. The degree of inconvenience to the defendant here is less than it might be if jurisdiction were based upon his citzenship. That lesser burden militates against the increased disinterest of the community when the claim is not brought against one of its citizens and the parallel decreased systemic responsibility of the court.

Fimally, if the defendant is not a citizen of the forum and has engaged in no activity there, personal jurisdiction may still be properly asserted if, for example, it placed its product in a stream of commerce that included the forum in which the product was purchased and caused an injury. ${ }^{211}$ In this instance, the forum, which is the situs of the product, is highly convenient for hitigating the injury and damages portion of the dispute. The community and the judicial system have an interest in the dispute and, therefore, a dismissal on grounds of forum non conveniens would again be inappropriate. ${ }^{212}$

A forum that takes into account the interests of alternative fora as well as its own in determining whether it may properly assert prescriptive jurisdiction may determine that such an assertion is uncalled-for, even though it has a cognizable interest in regulating a defendant's activity, if that interest is outweighed by the interest of a competing forum. Per-

210. Compare Dowling v. Richardson-Merrell, Inc., 727 F.2d 608 (6th Cir. 1984) (suit by British plaintiffs alleging birth defects caused by a drug manufactured and marketed in Britain, identical to a drug manufactured and marketed by defendant in United States, arguing that the defendant had concealed from the world-wide medical community and the National Health Authority in the United Kingdom findings concerning its drug; forum non conveniens dismissal affirmed, although similar suits were already pending in the district and although the forum had what the court characterized as a "minimal interest" in the safety of drugs developed or tested there and marketed abroad, primarily because of Britain's "particularly strong interest" when injury is caused there by a regulated industry) with Hodson v. A.H. Robins Co., 715 F.2d 142 (4th Cir. 1983) (suit by British plaintiff against the American manufacturer of an intrauterine contraceptive purchased, inserted, and removed in Britain; acknowledging that British law would apply, the trial court's refusal to dismiss the suit on the grounds of forum non conveniens was affirmed; evidence respecting the defendants' activities was in the forum, and the forum had a strong interest in regulating the safety of products manufactured within its borders). See also Watson v. Merrell Dow Pharmaceuticals, 769 F.2d 354 (6th Cir. 1985), decided in reliance upon Dowling and making clear, in its statement of the facts, the nonsense of the forum non conveniens dismissal which it nonetheless affirms as to the corporate defendant. For a discussion of other cases involving fact patterns parallel to Dowling, see Stein, supra note 18, at 837-40.

211. See supra note 41.

212. See also supra note 189 and accompanying text. But see supra note 40 . 
sonal jurisdiction might nevertheless be proper because of the defendant's acts in the forum related to the claim. In this situation, dismissal on grounds of forum non conveniens is hardly more justifiable than in the three fact patterns already discussed. Indeed, it is less justifiable, since convenience is obviously increased by readier access to additional evidence and witnesses.

The final possible permutation is that which was the genesis of the doctrine-a suit under general maritime law. In such a suit, the court will not have considered previously the interests of foreign states since there is no prescriptive jurisdictional issue involved. ${ }^{213}$ But because that is so, those foreign interests are not in a particular result but in the locale of the litigation and, again, are lessened by the plaintiff's decision to litigate away from home. The proposed personal jurisdiction analysis obviates the need to examine separately the other concerns reflected in the doctrine of forum non conveniens; assuming such jurisdiction is proper, the suit ought be retained. ${ }^{214}$

In a time of crowded dockets and proliferating application of forum law, the existence of forum non conveniens has undoubtedly provided a welcome discretionary method of ridding courts of at least some controversies better litigated elsewhere. But it has also lengthened litigation, cast yet another doubt upon the validity of a plaintiff's choice of forum, and at times excused sloppy jurisdiction analyses. The factors and policies to which the doctrine calls the court's attention are certainly relevant and important, but they are best considered in the jurisdictional contexts. There is no valid continuing role for forum non conveniens, only a repetitive one. The doctrine should be abolished.

213. The classic fact pattern involves a seaman's claim for tortious injury on the high seas brought against a third-party vessel. Assuming jurisdiction over the defendant is proper (frequently a dubious assumption in light of the arguments in Part I), a United States court would apply the maritime "communis juris," as interpreted by the United States, to determine liability. The forum would of course not attempt to interpret the "communis juris" according to foreign precedent. But the accepted governing body of law finds its source in the community of nations, not in any one sovereign. Liaw Su Teng v. Skaarup Shipping Corp., 743 F.2d 1140, 1144-46 (5th Cir. 1984).

214. See, e.g., Koke v. Phillips Petroleum Co., 730 F.2d 211 (5th Cir. 1984). The case is a good factual example of this permutation, and a classic wrong decision. British divers, injured in the Norwegian sector of the North Sea while working off a United States flag vessel, sued the shipowner, Phillips of Norway (the contractor), Phillips (parent of the contractor), and the owner of two subsidiary corporations that serviced the vessel. Suit was filed in the eastern district of Texas, the principal place of business of the shipowner. No other defendant had any apparent contact with Texas, but all were incorporated in Delaware. The court concluded that United States law did not apply, because the vessel approximated a fixed rig, see supra text accompanying note 189, and because of Norway's "substantial interest in regulating oil drilling and related activity off its coast." Id. at 220 (citation omitted). It then dismissed the suit on grounds of forum non conveniens. Neither that decision nor the assertion of personal jurisdiction was challenged. 
